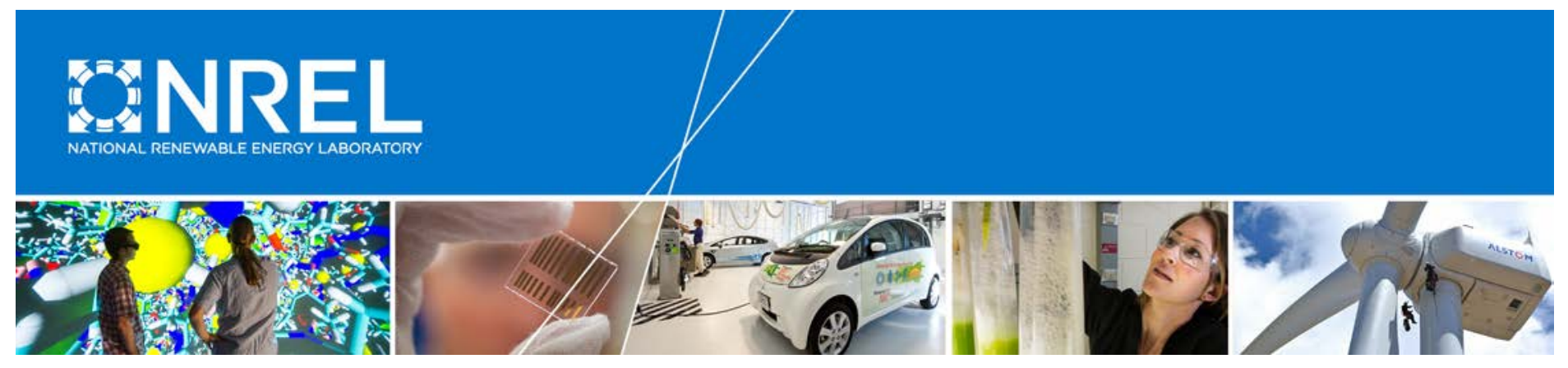

\title{
Fuel Cell Backup Power Unit Configuration and Electricity Market Participation: A Feasibility Study
}

Zhiwen Ma, Josh Eichman, and Jennifer Kurtz National Renewable Energy Laboratory

NREL is a national laboratory of the U.S. Department of Energy Office of Energy Efficiency \& Renewable Energy Operated by the Alliance for Sustainable Energy, LLC

This report is available at no cost from the National Renewable Energy Laboratory (NREL) at www.nrel.gov/publications.

Technical Report

NREL/TP-5400-67408

March 2017 


\section{Fuel Cell Backup Power Unit Configuration and Electricity Market Participation: A Feasibility Study}

Zhiwen Ma, Josh Eichman, and Jennifer Kurtz National Renewable Energy Laboratory

Prepared under Task No. 0654.1602

NREL is a national laboratory of the U.S. Department of Energy Office of Energy Efficiency \& Renewable Energy Operated by the Alliance for Sustainable Energy, LLC

This report is available at no cost from the National Renewable Energy Laboratory (NREL) at www.nrel.gov/publications.

National Renewable Energy Laboratory 15013 Denver West Parkway Golden, CO 80401

303-275-3000 • www.nrel.gov

\section{Technical Report}

NREL/TP-5400-67408

March 2017

Contract No. DE-AC36-08GO28308 


\section{NOTICE}

This report was prepared as an account of work sponsored by an agency of the United States government. Neither the United States government nor any agency thereof, nor any of their employees, makes any warranty, express or implied, or assumes any legal liability or responsibility for the accuracy, completeness, or usefulness of any information, apparatus, product, or process disclosed, or represents that its use would not infringe privately owned rights. Reference herein to any specific commercial product, process, or service by trade name, trademark, manufacturer, or otherwise does not necessarily constitute or imply its endorsement, recommendation, or favoring by the United States government or any agency thereof. The views and opinions of authors expressed herein do not necessarily state or reflect those of the United States government or any agency thereof.

This report is available at no cost from the National Renewable Energy Laboratory (NREL) at www.nrel.gov/publications.

Available electronically at SciTech Connect http:/www.osti.gov/scitech

Available for a processing fee to U.S. Department of Energy and its contractors, in paper, from:

U.S. Department of Energy

Office of Scientific and Technical Information

P.O. Box 62

Oak Ridge, TN 37831-0062

OSTI http://www.osti.gov

Phone: 865.576.8401

Fax: 865.576.5728

Email: reports@osti.gov

Available for sale to the public, in paper, from:

U.S. Department of Commerce

National Technical Information Service

5301 Shawnee Road

Alexandria, VA 22312

NTIS http://www.ntis.gov

Phone: 800.553 .6847 or 703.605 .6000

Fax: 703.605.6900

Email: orders@ntis.gov 


\section{Acknowledgments}

This project is part of the National Renewable Energy Laboratory (NREL) industry-inspired Laboratory Directed Research and Development program, and we acknowledge the funding support by NREL. The authors would also like to acknowledge Mark Cohen from Plug Power and Rich Burant, Eric Mettler, and Michael Balter from Altergy for reviewing this study. We also thank NREL Communications for help with the publication. 


\section{List of Acronyms}

ARRA

CAISO

DER

DOE

IC

ISO

MCFC

NREL

NYISO

PAFC

PEMFC

RTO

SOFC

VPP
American Recovery and Reinvestment Act California Independent System Operator distributed energy resources

U.S. Department of Energy

internal combustion

independent system operator

molten carbonate fuel cell

National Renewable Energy Laboratory

New York Independent System Operator

phosphoric acid fuel cell

proton exchange membrane fuel cell

regional transmission organization

solid oxide fuel cell

virtual power plant 


\section{Executive Summary}

This National Renewable Energy Laboratory industry-inspired Laboratory Directed Research and Development project evaluates the feasibility and economics of using fuel cell backup power systems in cell towers to provide grid services (e.g., balancing, ancillary services, demand response). The work is intended to evaluate the integration of thousands of under-utilized, clean, efficient, and reliable fuel cell systems that are already installed in cell towers for potential grid and ancillary services. The fuel cells are able to provide power for the cell tower during emergency conditions. We studied the strategic capability to enable information and energy exchanges with the power grid to add value for grid services that depend on location and time. Our economic analysis focused on the potential revenue for distributed telecommunications backup fuel cell units providing grid services. We studied current fuel cell backup power locations and regional grid service programs, and reviewed the development approach with industry. The grid service and configuration study for different operation modes identify opportunities for expanding backup fuel cell applications responsive to grid needs. The identified needs to realize the objectives of increased utilization and opportunities for further development of grid services are as follows:

1. Hydrogen delivery cost and availability are significant factors affecting the cost of generation for small-scale fuel cells to be distributed energy resources. Cheaper hydrogen sources, lowcost delivery, and economic storage methods need to be explored to improve the value added for fuel cell backup power units providing grid support.

2. Aggregated small units need communication and control hardware to coordinate with the grid. While some units currently include two-way power/data flows, all future units should consider two-way power/data flows and the implementation of communication/control units.

3. Opportunities should be explored for fuel cell backup units to participate in electricity markets to increase revenue, while supporting the grid.

4. Operators can schedule bidding and operation to maximize the value of operating fuel cells for periodic system checks, resulting in greater revenue and reduced operating cost.

5. The conceptual design of hardware and software architecture can be applied to other distributed energy resources for integration with the electric grid.

The study primarily focuses on how fuel cells can become a significant part of telecommunications backup power to reduce system costs, environmental impact, and dependence on fossil fuels, while ensuring continuity of reliable electricity and communications services for customers. The project's technical approach and methodology may extend fuel cell capabilities so as to access a variety of power markets. The outcomes of different application scenarios highlight commercially available fuel cell technologies and their integration methods for reliable power supply. 


\section{Table of Contents}

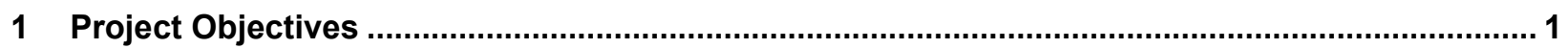

1.1 Fuel Cell Power Systems..................................................................................................... 1

1.2 Fuel Cell Backup Power System Integrated with Cell Towers ................................................ 5

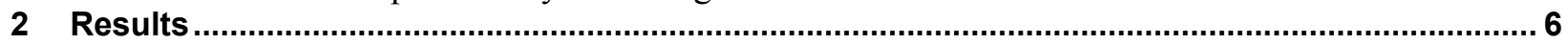

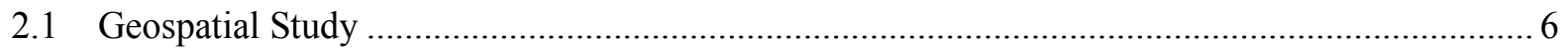

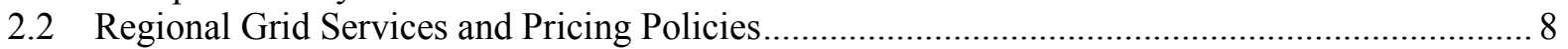

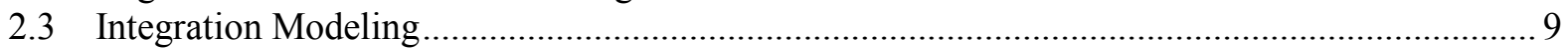

2.3.1 Energy and Information Flow for Grid Ancillary Services.......................................... 12

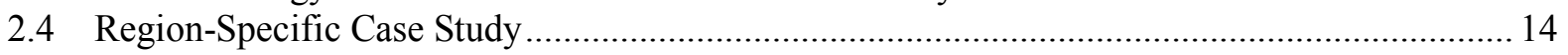

2.4.1 Energy Market Prices ............................................................................ 14

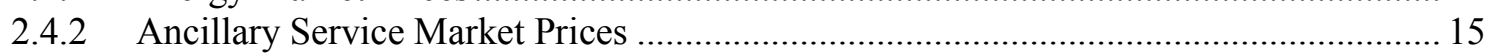

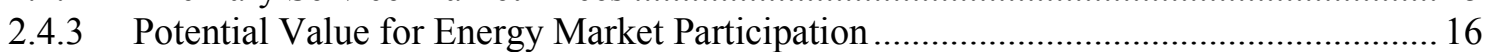

2.4.4 Potential Value for Ancillary Service Market Participation........................................... 17

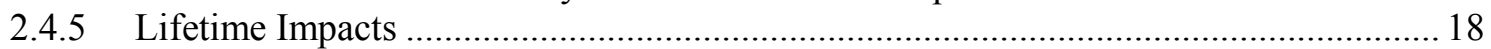

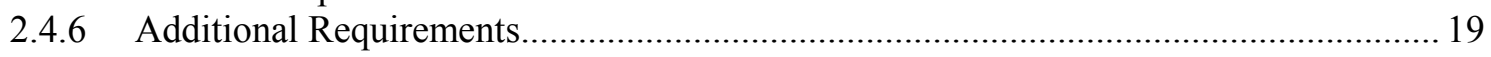

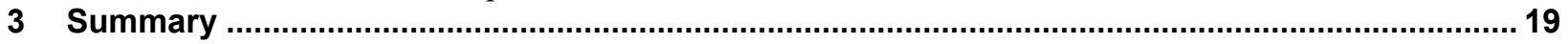

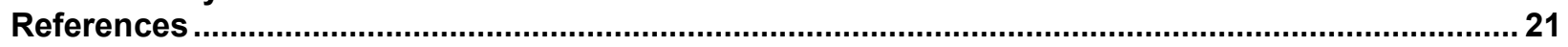

Appendix A: Alternative Configurations for Fuel Cell System Grid Support .................................. 23

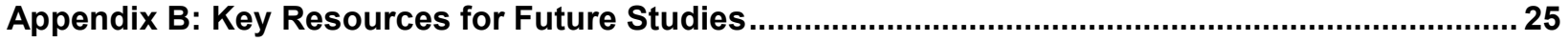




\section{List of Figures}

Figure 1. Fuel cell backup power system integrated with a cell tower with renewable (biomass, wind, and

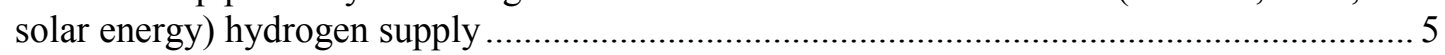

Figure 2. U.S. cell tower density map (Google map search) ............................................................. 6

Figure 3. ARRA-installed fuel cell backup power locations (to 2013, NREL [1]) ................................... 6

Figure 4. Working cell towers in New Jersey during the 2012 Hurricane Sandy (NREL) [1] ................... 7

Figure 5. T-Mobile added 300-plus backup power units in southern Florida since 2010.......................... 7

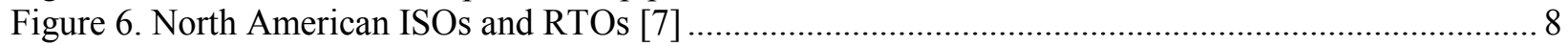

Figure 7. Control algorithm for fuel cell backup power operation with grid support ............................. 10

Figure 8. Load-connection options of fuel cell power system in standalone nanogrid, microgrid, and gridconnected modes [9]

Figure 9. Transactive energy and nano/microgrid functions for market participation and potential ancillary services [8]

Figure 10. Preliminary model architecture for load prediction based on weather and utility data to coordinate with fuel cell backup-power control algorithm ................................................. 13

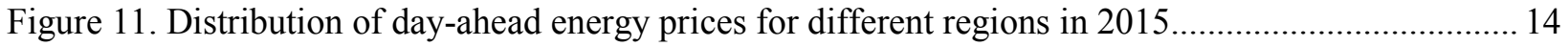

Figure 12. Distribution of real-time energy prices for several CAISO nodes in 2015 .......................... 15

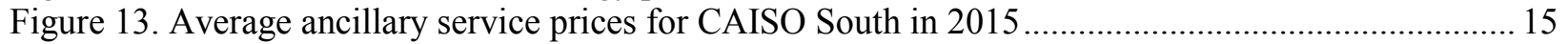

Figure 14. Electricity price by the fuel cell backup power ............................................................ 17

Figure 15. Relative capital cost increases for 72-hour systems from reductions in lifetime due to greater

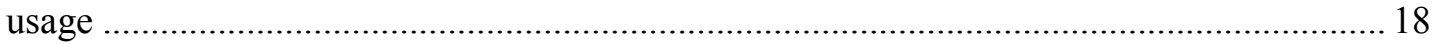

Figure B-1. DOE's ESIF can be a test base for a fuel cell backup power system integrated with renewable

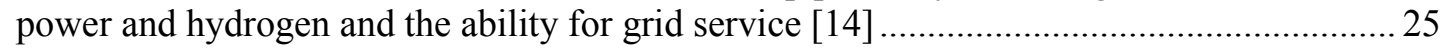

\section{List of Tables}

Table 1. Comparison of Major Types of Fuel Cells Relevant to Telecommunications Backup Power Applications [3]

Table 2. Comparison of Backup Power Using Batteries, IC Generators, and Fuel Cells for Cell Tower

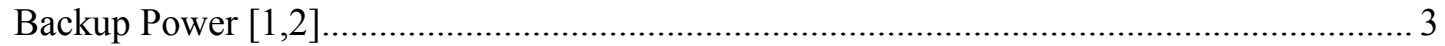

Table 3. Fuel Cell Backup Power Product by Major Suppliers .................................................................. 4

Table 4. Scale Comparison of DER Platforms [8] ............................................................................... 9

Table 5. Maximum Value for Reserves without Including Dispatch in CAISO in 2015 ........................ 17 


\section{Project Objectives}

Clean and efficient fuel cell power systems are an alternative power supply technology for distributed energy resource (DER) needs. One market in which they are especially attractive is with telecommunications companies that want many hours of backup power supply to avoid prolonged power outages and disruption of service to their customers. Backup power solutions using fuel cell system technologies offer improved network reliability, environmental benefit, and cost-effective operation over incumbent methods such as diesel backup power and batteries.

Between 2009 and 2012, the U.S. Department of Energy (DOE) supported the installation of more than 800 backup power fuel cell systems with American Recovery and Reinvestment Act (ARRA) funds [1]. Since 2007, more than 3,000 fuel cell systems have been installed at cellular facilities owned by telecom companies - Sprint, T-Mobile, Verizon, AT\&T, MetroPCS, and others - to power their facilities. The sites include both remote and urban locations. The fuel cell systems are networked and monitored remotely, and they provide benefits that include:

- Longer runtime (greater than 8 hours) to meet emergency power needs

- Quiet operation

- Rooftop installation capability

- Low total cost of ownership

- Low footprint.

According to a 2013 cost of ownership analysis [2], fuel cell systems could be and in some cases are already cost competitive with incumbent backup power technologies, particularly for long runtimes and with incentives. ${ }^{1}$ Current deployments are for emergency backup power only. The grid is fairly reliable under normal operating conditions (e.g., no natural disasters), so the backup systems are idle most of the time. Therefore, integrating under-utilized, efficient, and reliable fuel cell systems already installed in the United States for grid support can provide additional economic benefits for system owners and for grid reliability and energy costs.

The objective of this work is to study an approach to increase the use of installed fuel cell backup power systems. Furthermore, we evaluate the possibility of a microgrid using hydrogen fuel cells and a network of fuel cell backup power systems to implement information and energy flow for potential grid service, which could add a revenue stream for alternative use of the backup power. We first investigate the regional cell tower locations and needs, including hydrogen availability. Then we investigate the conditions and potential value that can be derived from expanding the fuel cell backup power capability to provide additional services to the grid.

\subsection{Fuel Cell Power Systems}

Four types of fuel cells have been developed, including the proton exchange membrane fuel cell (PEMFC), phosphoric acid fuel cell (PAFC), molten carbonate fuel cell (MCFC), and solid oxide

\footnotetext{
${ }^{1}$ The Emergency Economic Stabilization Act of 2008 put in place an investment tax credit for qualified fuel cell property. Equipment must be installed by 12/31/2016. The American Recovery and Reinvestment Act of 2009 expanded those incentives (https://energy.gov/eere/fuelcells/fuel-cell-technologies-office-recovery-act-projects).
} 
fuel cell (SOFC) [3]. They are categorized as low-temperature or high-temperature fuel cells based on their operating temperatures. Table 1 compares the advantages and disadvantages of the different fuel cells relevant to telecom backup power usage. All fuel cells can achieve well above $40 \%$ efficiency. High-temperature fuel cells such as PAFCs, MCFCs, and SOFCs can use natural gas supplied through a pipeline and avoid hydrogen delivery and storage needs. MCFCs and SOFCs, in particular, often work at temperatures ranging from $400^{\circ} \mathrm{C}$ to $600^{\circ} \mathrm{C}$, need thick insulation and a complicated system for fuel processing, and have high thermal mass. The cells are suitable for $100 \mathrm{~kW}$ or more of continuous operation for distributed generation without frequent transients or startup/shutdown. Currently, the scale of hydrogen/fuel cells for grid integration is focused more on prime power $(>100 \mathrm{~kW})$ stationary fuel cells rather than on smallscale $(<20 \mathrm{~kW})$ units. This study investigated the approach to extend the application of smallscale fuel cell backup systems by coordinating to the grid condition, thus increasing their utilization and economic return.

The PEMFC works at lower temperatures between $40^{\circ} \mathrm{C}$ and $120^{\circ} \mathrm{C}$. It uses industry-grade highpurity $(99.95 \%)$ hydrogen to prevent catalyst poisoning by contaminants, and it requires hydrogen or methanol delivery or on-site production and storage. PEMFCs can start up quickly and they rapidly ramp to the rated power; therefore, they represent a viable alternative emergency power source to batteries and internal combustion (IC) generators to provide power for portable electronics, stationary power, transportation, and, in this project, a backup power system for a cell tower.

Table 1. Comparison of Major Types of Fuel Cells Relevant to Telecommunications Backup Power Applications [3]

\begin{tabular}{|l|l|l|l|}
\hline Fuel Cells & MCFC & SOFC & PEMFC \\
\hline Advantages & $\begin{array}{l}\text { Can use natural gas as } \\
\text { fuel }\end{array}$ & Can use natural gas as fuel & $\begin{array}{l}\text { Fast power ramping } \\
\text { Highly scalable }\end{array}$ \\
\hline Disadvantages & $\begin{array}{l}\text { Relatively low power } \\
\text { density for } 100 \mathrm{~kW} \text { or } \\
\text { above } \\
\text { Requires continuous } \\
\text { operation for thermal mass }\end{array}$ & $\begin{array}{l}\text { Limited ramp rate due to } \\
\text { management of thermal } \\
\text { gradients } \\
\text { Not yet commercially } \\
\text { available }\end{array}$ & $\begin{array}{l}\text { Uses industry-grade } \\
\text { high-purity hydrogen } \\
\text { Need hydrogen delivery } \\
\text { or on-site production } \\
\text { and storage }\end{array}$ \\
\hline
\end{tabular}

Table 2 compares the advantages and disadvantages of the fuel cell backup power system relative to incumbent technologies. This comparison was assembled based on the authors' interpretation of detailed fuel cell data, literature search, and knowledge of site operation and requirements. The chart uses a range of "++" (much better than the comparison technologies) to "_- " (much worse than the comparison technologies). The " $\sim$ " symbol indicates that details are unknown or do not apply for that technology metric. Diesel IC generators have been widely used for portable and backup power, and they are commercially available at low cost and have a standard product series to serve the backup power market. However, they have several installation and operating issues that prevent their wide adoption for cell tower backup power applications. Local government agencies may limit IC generator installations because of emissions and noise concerns. Many cell antennas are located on top of buildings, where IC generators often cannot obtain a permit for installation. Another option, battery backup power, is quiet and easy to install. However, battery capacity depends on mass; high-capacity batteries are 
large and heavy, so they could incur weight/space limitations in confined spaces and on rooftops. The fuel cell option offers longer continuous runtimes at lower cost than battery power systems. Fuel cells also do not need to be recharged, and they perform better in cold weather than batteries do.

Table 2. Comparison of Backup Power Using Batteries, IC Generators, and Fuel Cells for Cell Tower Backup Power [1,2]

\begin{tabular}{|l|c|c|c|}
\hline & Fuel Cell & Diesel & Battery \\
\hline Reliability & + & - & + \\
\hline Capital cost (\$/kW) & - & + & ++ \\
\hline Extended run time & ++ & ++ & -- \\
\hline Emissions & ++ & - & ++ \\
\hline Noise & + & - & ++ \\
\hline Weight & + a & + & + \\
\hline Efficiency & + & - & ++ \\
\hline Annual fuel cost & $-{ }^{\mathrm{b}}$ & - & $+\mathrm{c}$ \\
\hline Annual maintenance cost & + & - & ++ \\
\hline Maintenance frequency & ++ & - & $\sim$ \\
\hline Refurbishment & + & + & -- \\
\hline Remote conditioning and check & + & - & $\sim$ \\
\hline Operation lifetime & + & ++ & -- \\
\hline Ambient conditions & + & + & - \\
\hline
\end{tabular}

${ }^{a}$ Fuel cell system only without the weight of hydrogen storage.

b Current cost of hydrogen (2016) is still high.

c Cost can be worse if batteries were added for air conditioning.

Compared with IC generators and batteries, PEMFC systems are clean, efficient, and suitable for cell tower power backup usage or other critical power supply needs. The nominal cost of PEMFCs is still higher than that of IC generators and batteries at a certain capacity. However, a 2012 National Renewable Energy Laboratory (NREL) report indicates that under certain implementation conditions, the PEMFC system can be cost effective and has $99.5 \%$ reliability for successful starts [4]. PEMFCs can also take advantage of clean-energy incentives, which reduces the installation cost and makes them more cost competitive. ${ }^{2}$ Additionally, the long run time and low on-site emissions of PEMFCs encourages greater use of these resources. Diesel generators, for instance, can only operate during a limited portion of the year, which strongly discourages their participation in providing additional services to the grid. Also, with long run time, PEMFCs for backup power can provide grid services by changing load, while ensuring that the critical load is covered. With the right inverter and controls, the backup systems could provide local grid support. Because batteries have limited energy capacity, owners are far less

\footnotetext{
${ }^{2}$ The clean-energy incentives expired after December 31, 2016.
} 
interested in speculating on additional revenues from grid services at the expense of not having sufficient energy during an outage event.

Implementing a backup power system for the cell tower will add costs for telecom companies; however, the benefits of reliable cell service can outweigh the increased cost. After a Hurricane Katrina recommendations review, a Federal Communications Commission ruling required telecom and wireless companies to provide backup power for cell sites and remote telecom facilities [5]. The ruling was put on hold by the court challenges from telecom companies, primarily due to cost and permitting issues. The backup power system requires extended operating hours of 8 to 32 hours ( 8 hours in the Federal Communications Commission ruling), which limits the use of batteries. Fuel cells overcome all the technical drawbacks of batteries (duration) and IC generators (emissions, noise); however, a hurdle in deploying fuel cell backup power is cost. Continuing efforts to reduce fuel cell cost, optimize system configuration, and maximize the fuel cell backup power economic return may further reduce the owner cost. Those efforts include measures to reduce operating cost by remote monitoring and to provide grid services to increase the economic benefits of the backup power system.

Three major suppliers in the United States and Canada provide PEMFC power systems for cell towers. Table 3 summarizes the technology specifications for their backup power units. All systems were designed to support cell tower facilities and end-user requirements. Most of the systems are already deployed in the field and meet operating temperatures in all environmental conditions. The power module can be adapted to different cell tower locations and layouts.

Table 3. Fuel Cell Backup Power Product by Major Suppliers

\begin{tabular}{|c|c|c|c|c|c|}
\hline Supplier & Product & $\begin{array}{l}\text { Power } \\
\text { (per unit }^{3} \text { ) }\end{array}$ & $\begin{array}{l}\text { Operating } \\
\text { Temperature } \\
\left({ }^{\circ} \mathrm{C}\right)\end{array}$ & $\begin{array}{l}\text { Weight } \\
\text { (kg) }\end{array}$ & $\begin{array}{l}\text { Electric } \\
\text { Output } \\
\left(V_{D C}\right)\end{array}$ \\
\hline PlugPowera / ReliOn & GenSure & $0.2-10 \mathrm{~kW}$ & $-40-50$ & $113-148$ & $12-48$ \\
\hline Altergy $^{b}$ & $\begin{array}{l}\text { Freedom } \\
\text { Power System }\end{array}$ & $1-100 \mathrm{~kW}$ & $-40-50$ & $35-1500$ & $24-48$ \\
\hline Ballardc/Ida Tech & $\begin{array}{l}\text { ElectraGen-H2 } \\
\text { ElectraGen-ME }\end{array}$ & $1.7-5 \mathrm{~kW}$ & $-20-48$ & 40 & $48-55$ \\
\hline
\end{tabular}

a Source: http://www.plugpower.com/products/gensure/product-literature/

b Source: http://www.ballard.com/power-products/

c Source: http://www.altergy.com/products-2/freedom-power-technology/

The power capacity of the backup system used for cell towers is typically $4-6 \mathrm{~kW}$. The product line from fuel cell manufacturers can supply power packages for a wide range of power demands. The fuel cell stack can be fabricated in a modular unit that has the flexibility to scale within a wide range. Fuel cells generate DC electricity, and their electric output can connect directly to telecom equipment from $12 \mathrm{~V}$ to $48 \mathrm{~V}$ without using a DC/AC inverter. The fuel cell modules are enclosed in power cabinets with formed and welded metal construction that can

\footnotetext{
${ }^{3}$ Multiple units can be installed to increase the total system power.
} 
withstand all weather conditions $\left(-40^{\circ} \mathrm{C}\right.$ to $\left.+50^{\circ} \mathrm{C}\right)$. The system used for emergency power supply could work reliably for 15 years.

\subsection{Fuel Cell Backup Power System Integrated with Cell Towers}

Fuel cell systems can provide a reliable source of emergency backup power, particularly for mission-critical operations such as telecommunication and data centers, where uninterrupted power is essential for operation. Fuel cell systems are used by telecom companies to provide backup power for telecom base stations, repeaters, cell towers, and other electronic systems, particularly those requiring DC power supply. Fuel cell backup power systems can also address the challenges of intermittent grid disruption, power outage, and network interruptions due to natural disasters with a cleaner and a more reliable supply of power than incumbent methods. Due to their high efficiency, long run times, reliability, and availability of financial incentives, backup power systems are a good application for fuel cells.

Figure 1 shows a fuel cell backup power system integrated with a cell tower with renewable hydrogen. Currently, a typical installation of telecommunications cell tower fuel cell backup power does not have the renewable hydrogen generation system components. The system consists of a power generator (i.e., fuel cell stack, typically within a protective enclosure), hydrogen from renewable sources, grid power supply, and integration to the base station at the cell tower. According to the fuel cell system providers and telecom users, the fuel cell power system is often installed in accordance with safety and operation rules, and in compliance with local laws and code requirements. Installation and connection to local power distribution systems typically requires certified installers depending on the national or local codes, including permits and inspections by local enforcement personnel.

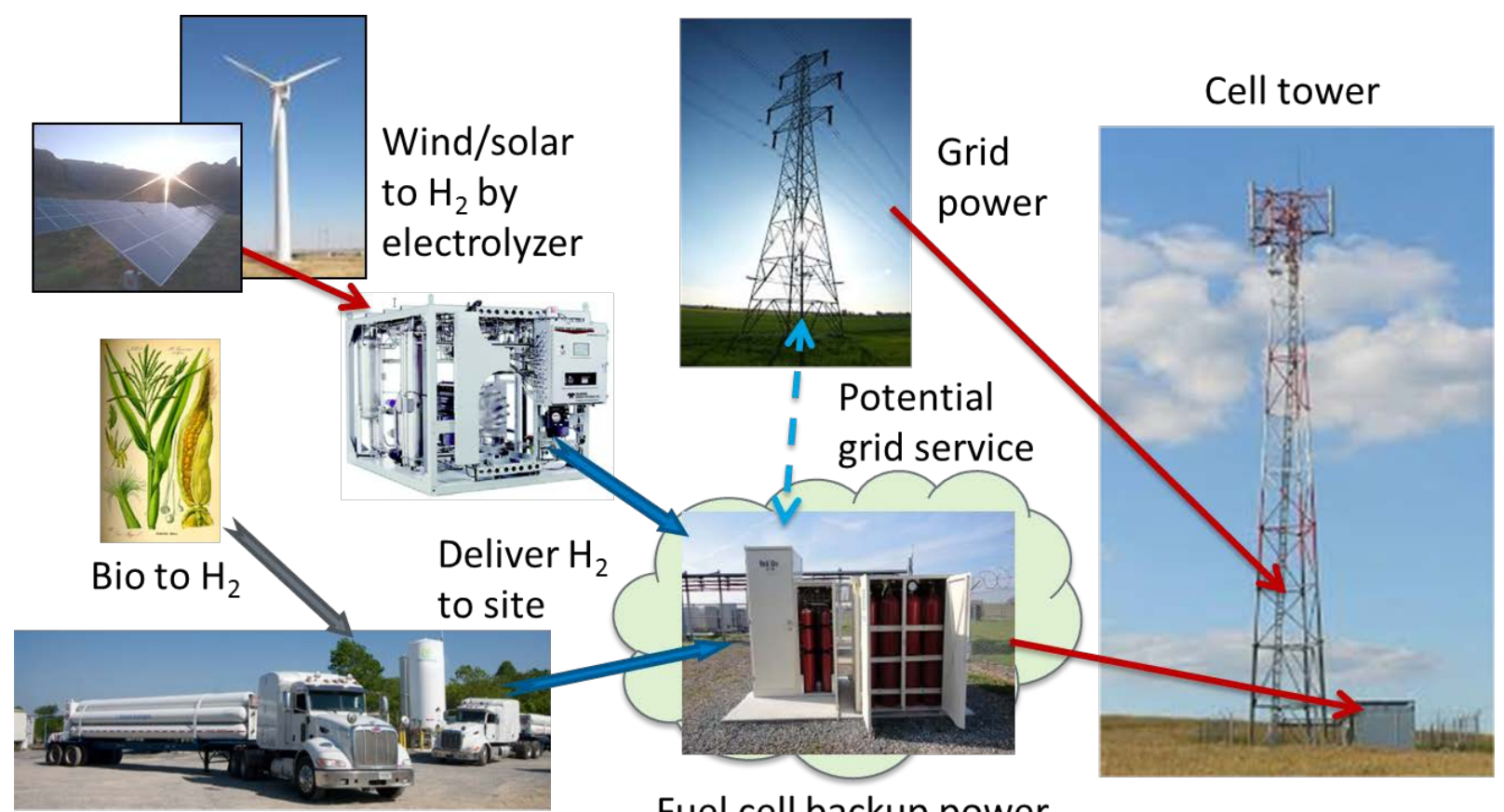

Fuel cell backup power

Figure 1. Fuel cell backup power system integrated with a cell tower with renewable (biomass, wind, and solar energy) hydrogen supply 
The hydrogen level may be monitored remotely to allow the user to maintain the fuel supply. The fuel cell backup system requires a regular, automated status check of operability to ensure that the system is able to respond when required. This status check involves turning on the system to check system status and hydrate the stack membrane periodically.

\section{Results}

The first two project tasks include geographic mapping to identify suitable telecommunication areas and regional grid, and investigating the fuel cell backup power deployment strategy for notable benefits or particular services in suitable locations. Based on the identified needs and regions suitable for backup power systems, the remaining project tasks look at enhancing the capabilities of fuel cell backup power systems to improve their usability by providing grid services and adding value beyond the original purpose as emergency power supply.

\subsection{Geospatial Study}

Figure 2 shows the U.S. cell tower density map from a Google map search. The map shows that there is a high density of cell tower distribution in the Northeast and Southeast. These areas are also affected by strong storms and hurricanes, where reliable communications by backup power systems is needed. From the map in Figure 2 and utility regional information, we can identify the geographically sensitive regions with high electric cost, low grid reliability, more frequent natural disasters, utility rate structures that reward grid service, remote areas that need high electric availability, and densely populated areas sensitive to pollutant emission, noise, and leakage of contaminating materials.

More than 3,000 fuel cell backup systems totaling 16.3 MW have been installed through 2013. The subset of telecommunications installations funded with DOE/ARRA funding is shown in Figure 3. Other deployment examples include a greater than $1 \mathrm{MW}$ installation in California by Plug Power (formerly ReliOn) and more than 8.3 MW deployed by Altergy for telecom usage. The startup reliability of those systems was $99.5 \%$ [4]. Although some system capacities were larger than $10 \mathrm{~kW}$, most of the systems were in the 4-6 kW range. Modules of smaller fuel cell units could be combined to adjust the system size to an individual site's needs.

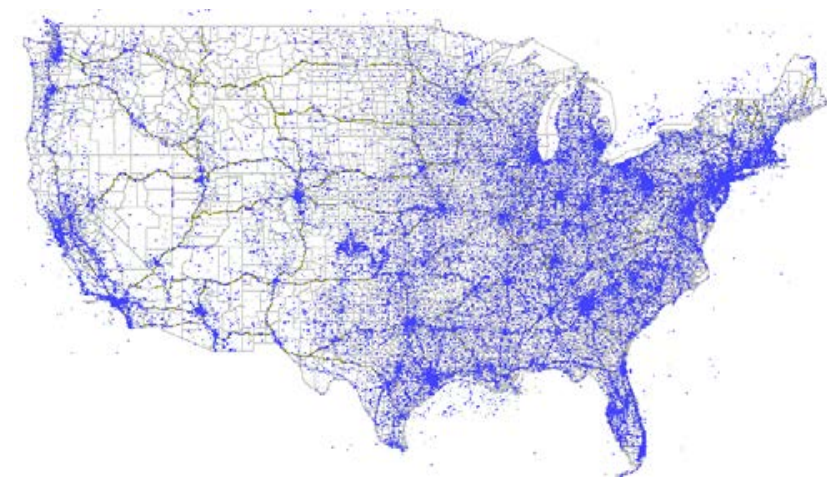

Figure 2. U.S. cell tower density map (Google map search)

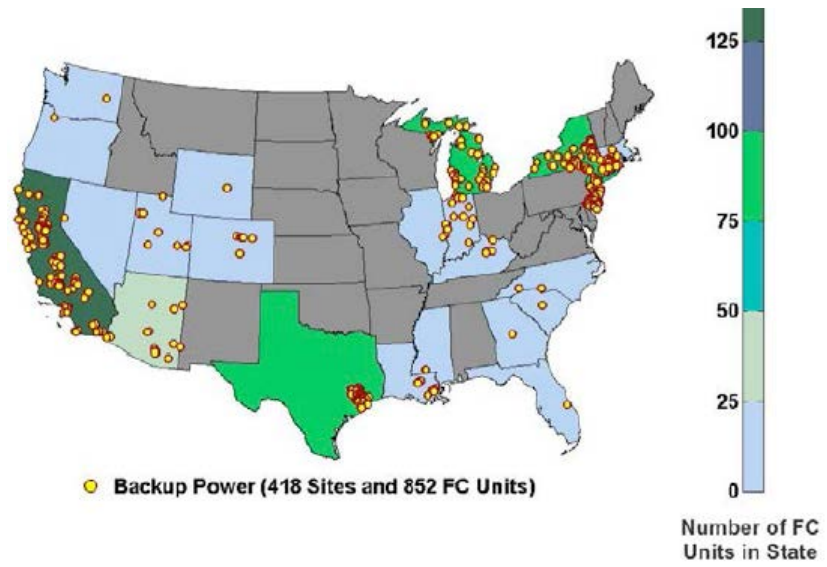

Figure 3. ARRA-installed fuel cell backup power locations (to 2013, NREL [1]) 
Figure 4 shows that during the 2012 Hurricane Sandy, the cell towers in New Jersey could continue operation after grid blackout. Some 122 ARRA-funded backup power systems were installed in the Federal Emergency Management Agency Modeling Task Force Hurricane Sandy impact area. Between October 29, 2012, and November 12, 2012, five of the ARRA sites that reported data operated during Hurricane Sandy for 112 total hours of operation.

Figure 5 shows the installed backup power systems on the cell tower sites in hurricane-prone southern Florida. From this mapped information, cell sites located near the disaster areas would benefit from fuel cell backup power systems for providing long-duration, non-interruptible service during grid blackouts and emergency power needs. The tower sites can also be searched from the cell tower information portal: http://www.cellreception.com/towers/.

A major concern often raised in deploying fuel cell power generation systems is the availability of hydrogen for fueling the PEMFC system. Hydrogen is typically delivered by industrial gas companies in either bottles or tube trailer delivery trucks. The hydrogen is produced from steam methane reforming, which is presently the lowest-cost production method. There are ongoing activities that are exploring the benefits of a more ubiquitous roll-out.

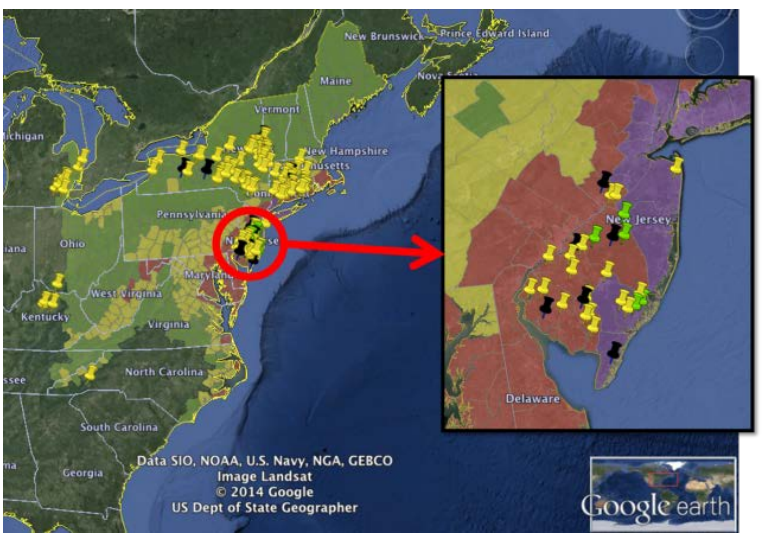

Figure 4. Working cell towers in New Jersey during the 2012 Hurricane Sandy (NREL) [1]

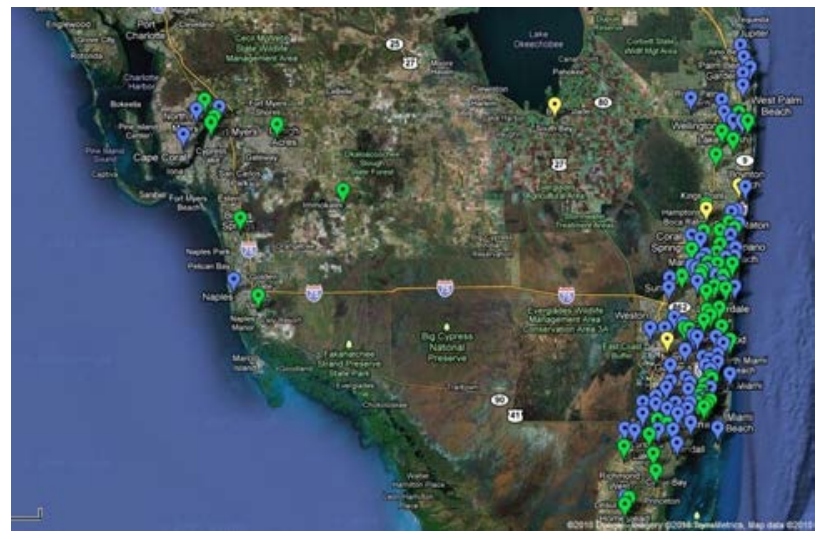

Figure 5. T-Mobile added 300-plus backup power units in southern Florida since 2010

With the increasing amount of solar and wind power added to the grid, grid service by backup power could play a role for balancing the grid and providing additional services. Small backup fuel cells can be networked in concert to react to grid demand, and they may reduce grid congestion in some densely populated areas where demand could fluctuate significantly at times. The quick response of fuel cells to power demand can provide reliable power supply for telecommunications and other critical facilities. The installed fuel cell backup power for emergency power purposes may under-utilize the fuel cell power generation capability and can benefit from the expanded use of the systems for grid needs. Specifically, grid outages can occur when the grid is stressed with high demand and limited available supply. Operating the backup power during times when the grid is stressed can prepare the backup system in the event that the grid goes down. In this way, backup units are already operating during high-stress times and can kick off the grid easier and with potentially less impact to their customers if the grid actually fails. 


\subsection{Regional Grid Services and Pricing Policies}

We studied the regional grid and pricing policies to identify potential niche markets where fuel cell backup power can play a role in grid ancillary service. Several regions across the country have organized electricity markets. Figure 6 shows the map of North American independent system operators (ISOs) and regional transmission organizations (RTOs). These regions coincide with population density and cell tower density.

In 2014, Eichman studied the minimum capacity requirements for bidding demand response devices into electricity markets and found that the threshold for the bidding capacity is high compared to the size of an individual backup power fuel cell unit. However, multiple units can be aggregated to achieve the required size [6]. The study indicates that the thresholds for ISOs are as low as $100 \mathrm{~kW}$ but can be as high as $50 \mathrm{MW}$. Since the publication of the 2014 report, the threshold continues to fall and opportunities for aggregation continue to expand.

Providing grid services may increase the value of the fuel cell backup system and decrease the installation payback time. However, the threshold of the power capacity for grid service is higher than the individual fuel cell power rating. A network of fuel cell backup power with aggregated coordination may provide grid service capability. Implementing real-time response may favor aggregation of the networked fuel cell backup power to create a virtual power plant that serves regional need.

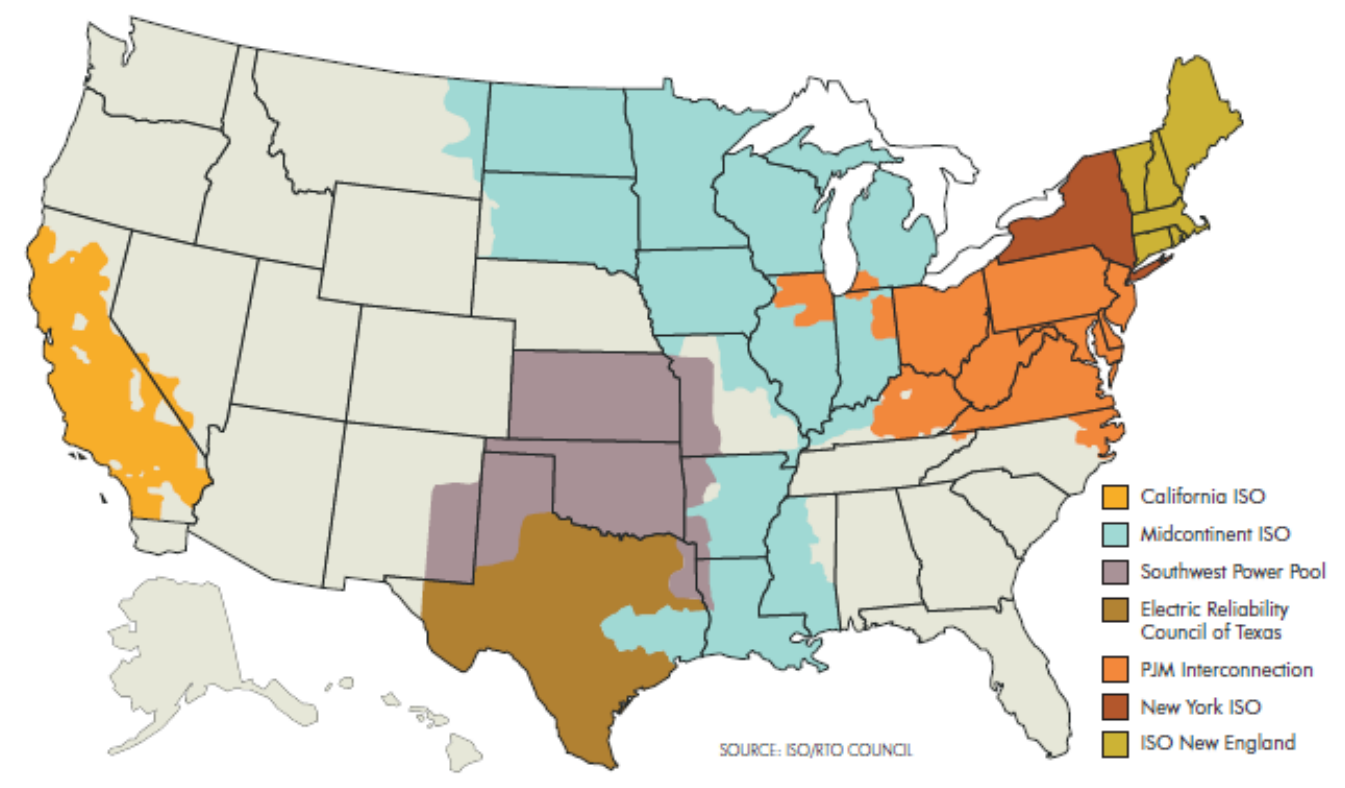

Figure 6. North American ISOs and RTOs [7]

Bidding into electricity markets or even participating in demand response programs requires verifiable increase in generation - or equivalently, reduction in system load. The cell tower power demand is a fraction of the available power from the fuel cell, so without additional electrical infrastructure (i.e., export capability), the fuel cell can only provide generation/load reduction equal to the cell tower power demand at that time. And the backup system is not designed to export power. This reduces the potential revenue from providing grid services unless 
additional equipment is installed. This trade-off is a consideration when determining the value of a specific system.

\subsection{Integration Modeling}

We studied backup power for emerging and regulatory needs and then looked at the possibility for grid service and the system configuration needs. Table 4 compares the scale and characteristics of distributed power generation in three modes: nanogrids, microgrids, and virtual power plants (VPPs). The table was adapted from Navigant Research's microgrid research [8]. Table 4 lists the DER relationship and interaction with the grid of scales, resources, market impact, and applications.

With respect to Table 4, the backup power for a cell tower can be disconnected from the utility and operate in nanogrid mode. Although the disconnected mode is simple and performs the essential function for emergency power, the economic benefit and return on investment for the system owner is limited to emergency outage situations. Considering microgrids or VPPs could improve the system functions on the grid scale and improve economic benefits by relying on lower-cost electrons during normal grid conditions and either 1) supplement revenue with electricity markets or 2) generate electricity during expensive peak-demand hours by assuming that the electricity cost is greater than the cost to generate on site. This concept is explored in this report.

Table 4. Scale Comparison of DER Platforms [8]

\begin{tabular}{|l|l|l|l|}
\hline Capabilities & Nanogrids & Microgrids & VPPs \\
\hline Grid-tied & Sometimes & Sometimes & Always \\
\hline Islanding & Usually & Yes & No \\
\hline Storage & Most of the time & Often & Sometimes \\
\hline Geographic range & Confined to load & Confined to network & Wide and variable \\
\hline Resource mix & Static & Static & Mix and match \\
\hline Grid connection & $\begin{array}{l}\text { Mostly behind the } \\
\text { meter }\end{array}$ & Mostly behind the meter & $\begin{array}{l}\text { Mostly transmission } \\
\text { node }\end{array}$ \\
\hline Market impact & Retail & $\begin{array}{l}\text { Retail first, then } \\
\text { wholesale }\end{array}$ & $\begin{array}{l}\text { Wholesale first, then } \\
\text { retail }\end{array}$ \\
\hline $\begin{array}{l}\text { Application } \\
\text { example }\end{array}$ & $\begin{array}{l}\text { Cell tower backup } \\
\text { power }\end{array}$ & $\begin{array}{l}\text { Fuel cell / building- } \\
\text { integrated generation }\end{array}$ & $\begin{array}{l}\text { Energy cloud with } \\
\text { connected storage }\end{array}$ \\
\hline
\end{tabular}

The backup power system can participate in energy markets by using the fuel cell to offset system power demand. To participate in the energy markets, the cost of energy should be calculated to make sure that the economic return from the utility is higher than the generation cost including fuel feedstock and delivery costs. The backup system can also provide ancillary services by bidding the system demand as the potential reserve capacity. The types of services provided and the revenue for participation will be explored in the following sections. The fuel cell operation control algorithm in Figure 7 follows the top-down sequences wherein the top operation could supersede the lower operation. The program in Figure 7 communicates with the grid to obtain grid conditions for necessary operation of the backup fuel cells. Meanwhile, the 
fuel cell conditions, such as hydrogen level and maintenance need, are also monitored and alarmed for situations that require operator attention. The monitoring can be in a remote, central office to indicate whether a system is available for grid-support operation.

Figure 7 shows the sequence of operation with emergency backup power generation as the highest-priority function. When the hydrogen level is sufficient and the emergency condition is satisfied, the control algorithm will optimize the running condition by comparing retail electricity rate, energy market price, and ancillary service need to determine if a beneficiary run can be in lieu of a system check. If a beneficiary run is preferred, then the fuel cell can run for both power generation and maintenance hydration. This is a preferred operating mode such that the operation of fuel cell systems could be synchronized with the fuel cell maintenance timing and hydration need while meeting the grid demand by generating power in the peak pricing period. The optimization program enables cost reduction by scheduling hydration cycles during periods that can improve revenue, instead of scheduling randomly. An additional check includes operation time because these systems are not designed for continuous operation and too many hours of operation may present warranty and reliability issues.

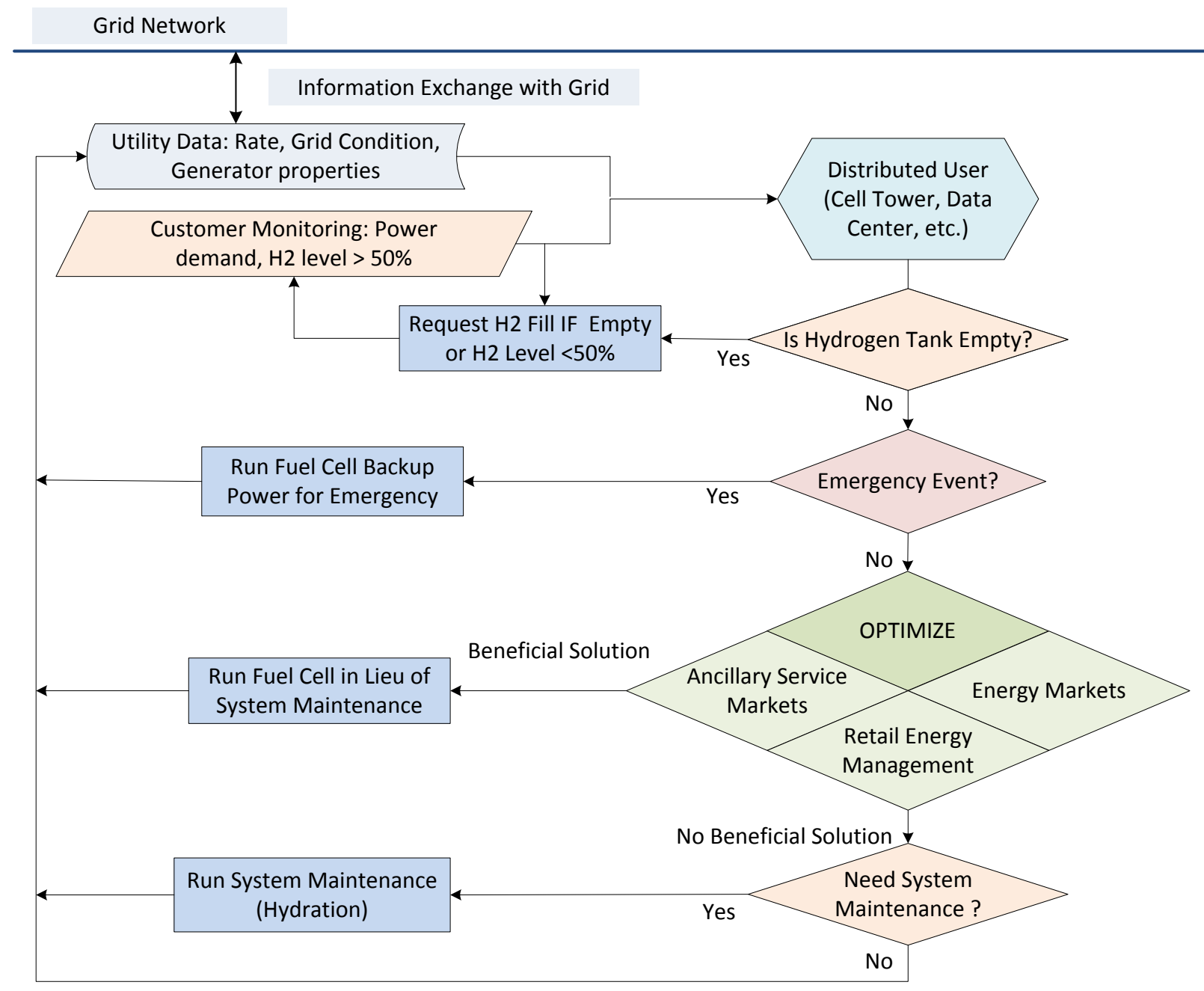

Figure 7. Control algorithm for fuel cell backup power operation with grid support 
The control algorithm as shown in Figure 7 can be embedded in a device, which can communicate with the grid/microgrid. The device may coordinate with other renewablegeneration devices such as solar panels or wind turbines to determine the optimum generation for maximizing the reliability. The collected information of grid electricity price or DER need will be compared with the backup power-generation cost to decide if the backup power generation should start and supply the power to the cell tower, offsetting the grid demand from the cell tower. Additional hardware and logic control for the grid connection is needed, and examples of such connections are shown in Figure 8, which shows a schematic of the electric connections of nanogrid, microgrid, and grid-connected modes.

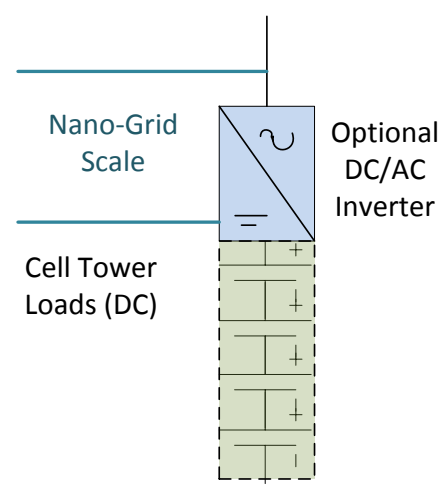

Standalone nanogrid mode

Upon grid outage, backup supplies power locally. Seamless backup power will be available to hard-wired customer critical loads.

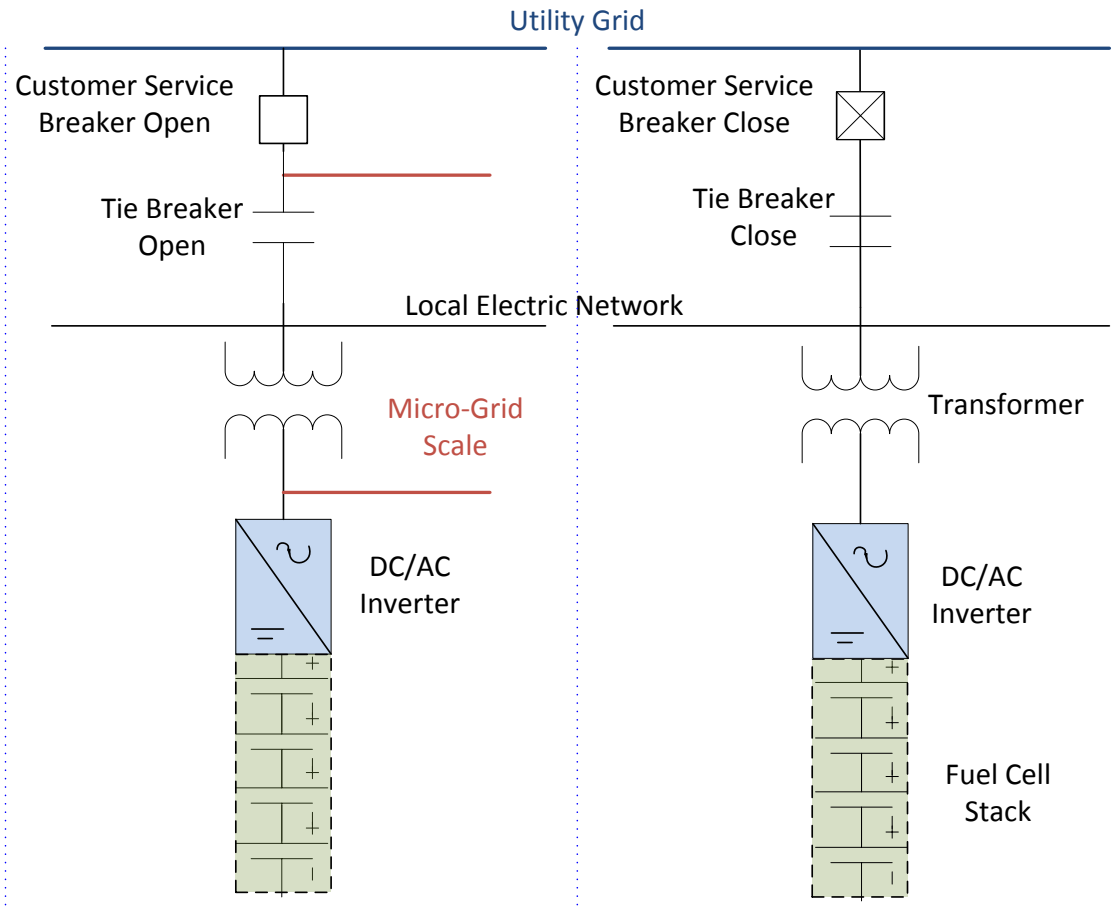

Microgrid mode

After a grid outage, facility loads are reconnected in a controlled manner to the fuel cell and other on-site sources.

\section{Grid-connected mode}

Fuel cell synchronizes to the local utility grid and offsets part or all of the load demand of the facility, reducing power needed from the utility.

Figure 8. Load-connection options of fuel cell power system in standalone nanogrid, microgrid, and grid-connected modes [9]

In the event of power loss, the power supply to the backup equipment automatically isolates from the grid and the local backup power supply delivers its own power to the site without any interruption or loss in power quality. The circuit diagram in Figure 8 shows that electric circuits from the standalone nanogrid mode to microgrid or grid-connected mode need additional equipment - DC/AC inverter, circuit breakers, and transformer-over the current basic fuel cell system. The cost of additional equipment may not be justified for a backup system with a small number of fuel cells $(4-6 \mathrm{~kW})$ to provide grid services. Once the system capacity increases and meets the condition for direct grid connection, the diagram illustrates the electric circuit and 
required components for different configurations, including those that allow bidirectional power flow.

Operating individual small-scale (4-6 kW) fuel cell systems may not be economically viable for grid ancillary service and DER needs. Implementing real-time response may favor aggregation of fuel cell backup systems. A network of fuel cell backup power with aggregated coordination is considered below. Expanding the number of backup fuel cell systems may increase the opportunity for generating power in parallel with other generation sources in microgrid or gridtied operations [9].

\subsubsection{Energy and Information Flow for Grid Ancillary Services}

As the grid evolves toward an interconnected bidirectional network with central and distributed resources, grid operators will need to be informed in their short-term and long-term planning to anticipate the complex interdependencies that exist in the network. The integration of the grid and the information network is helping to reinvent the way that energy producers, utilities, and consumers interact. Several of these changes are summarized by Navigant Research in what they call the "energy cloud" [10]. These changes are the result of both a fundamental shift in how electricity is generated and distributed, as well as an evolution of the traditional relationship among stakeholders across the electrical grid.

Figure 9 shows a conceptual platform for backup power to be connected into a microgrid and to form VPPs through control and communication. The utility layer uses a two-way information and power-flow representation. Similar to the energy cloud, the idea of changing passive consumers into active prosumers brings us to a discussion of transactive energy systems [11]. In addition to available aggregation techniques, the transactive energy architecture gives smallscale fuel cell systems a platform to provide support for the grid in a variety of ways, including through market participation and demand response programs.
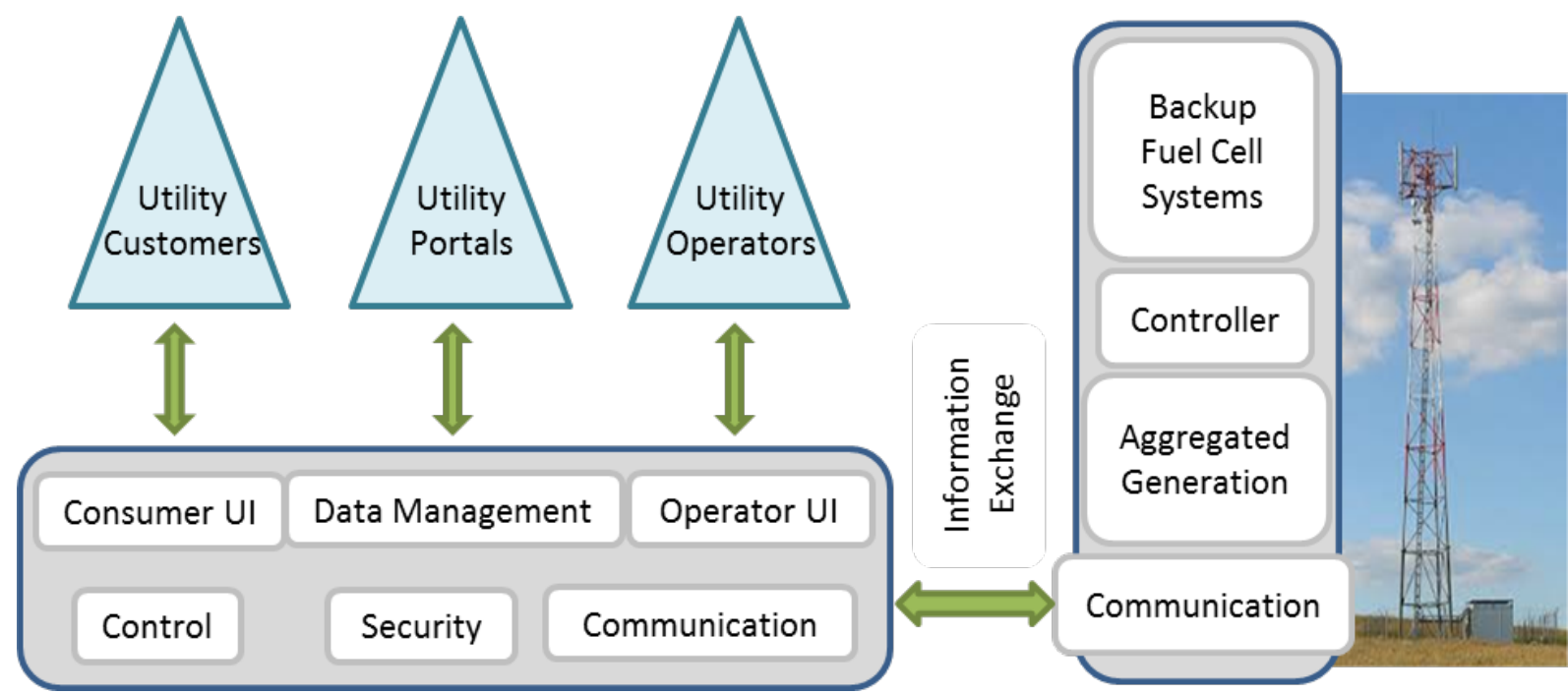

Figure 9. Transactive energy and nano/microgrid functions for market participation and potential ancillary services [8] 
Figure 10 shows an example of the analytic model including demand forecast, together with weather and energy data, to predict the electricity price. The program for demand forecasting in the left-hand box of the flowchart takes utility production data, weather condition, and emergency events such as grid black-out or natural disaster to predict the load. The demand forecast model in the middle box can use a statistical method or time-series analysis, which are methods that already exist in a variety of software packages. Then the backup power generation cost is computed and compared to the utility price. If economic benefits can be realized from providing grid services, then the control logic allows the backup power unit to provide those services. The operation may depend on improving hydrogen fueling, storage, and delivery economics for better hydrogen availability while ensuring that sufficient backup operation is maintained.

The grid-service modeling concept can be based on utility data analysis and dynamic pricing. Dynamic pricing involves an electricity price that varies based on time of day, system demand, and other factors. The concept of small-generation devices participating in dynamic pricing in a utility is fairly new, whereas time-of-use rates are more commonly used for changing the operation of loads.

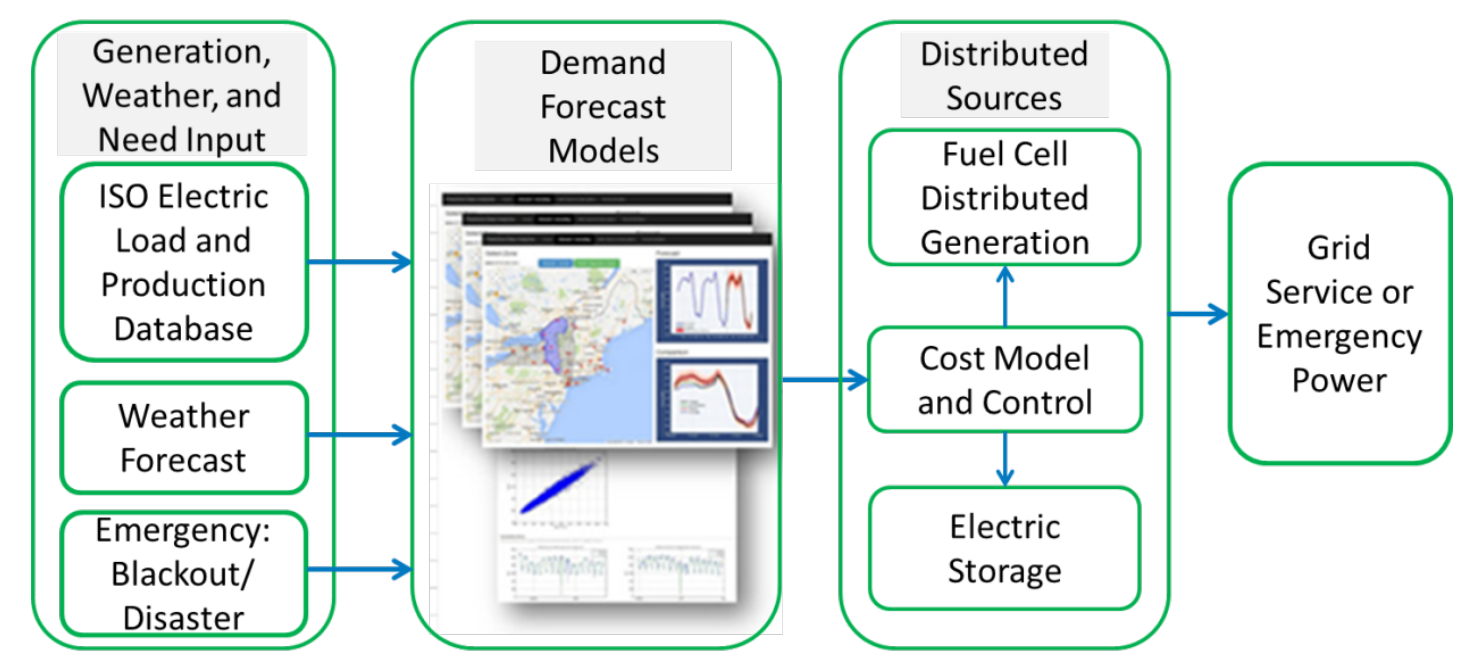

Figure 10. Preliminary model architecture for load prediction based on weather and utility data to coordinate with fuel cell backup-power control algorithm

Navigant Research examined the market drivers and barriers for the global dynamic-pricing market. Dynamic pricing - including real-time pricing, critical-peak pricing, peak-time rebates, and variable-peak pricing - could spread widely and rapidly in the next decade. According to a report by Navigant Research [10] on global market analysis and forecasts, the number of customers on dynamic-pricing rates globally is expected to rise from about 3.4 million customers in 2016 to 113.3 million in 2025 . The growth in customers taking advantage of dynamic pricing through utilities or system operators can be applied to a broader set of DERs, including fuel cell backup power systems. 


\subsection{Region-Specific Case Study}

This case study with market participation considers the energy market for three regions in California and the Northeast, where backup-power fuel cell systems are already installed and operating.

\subsubsection{Energy Market Prices}

Participation in energy markets involves increasing generation based on the amount of energy that is bid into energy markets. These markets are typically settled day-ahead or real-time. The first step to determining the value for market participation of backup fuel cell systems is to understand the conditions that will result in positive revenue for the system. We examine the price profiles for different regions in the United States. Figure 11 shows the publically available day-ahead price distributions for three different ISOs - the California Independent System Operator (CAISO), PJM, and the New York Independent System Operator (NYISO). ${ }^{4}$ To generate positive revenues for fuel cell participation in the energy markets, the market prices must be higher than the cost of purchasing and delivering hydrogen. The prices in all regions are around \$30-\$40/MWh. The tails of the distribution are smaller for CAISO, which does not experience any hours greater than $\$ 200 / \mathrm{MWh}$, whereas PJM has an average of 10 hours that are above $\$ 400 / \mathrm{MWh}$ per region and NYISO has an average of 1 hour above $\$ 400 / \mathrm{MWh}$ for each region.

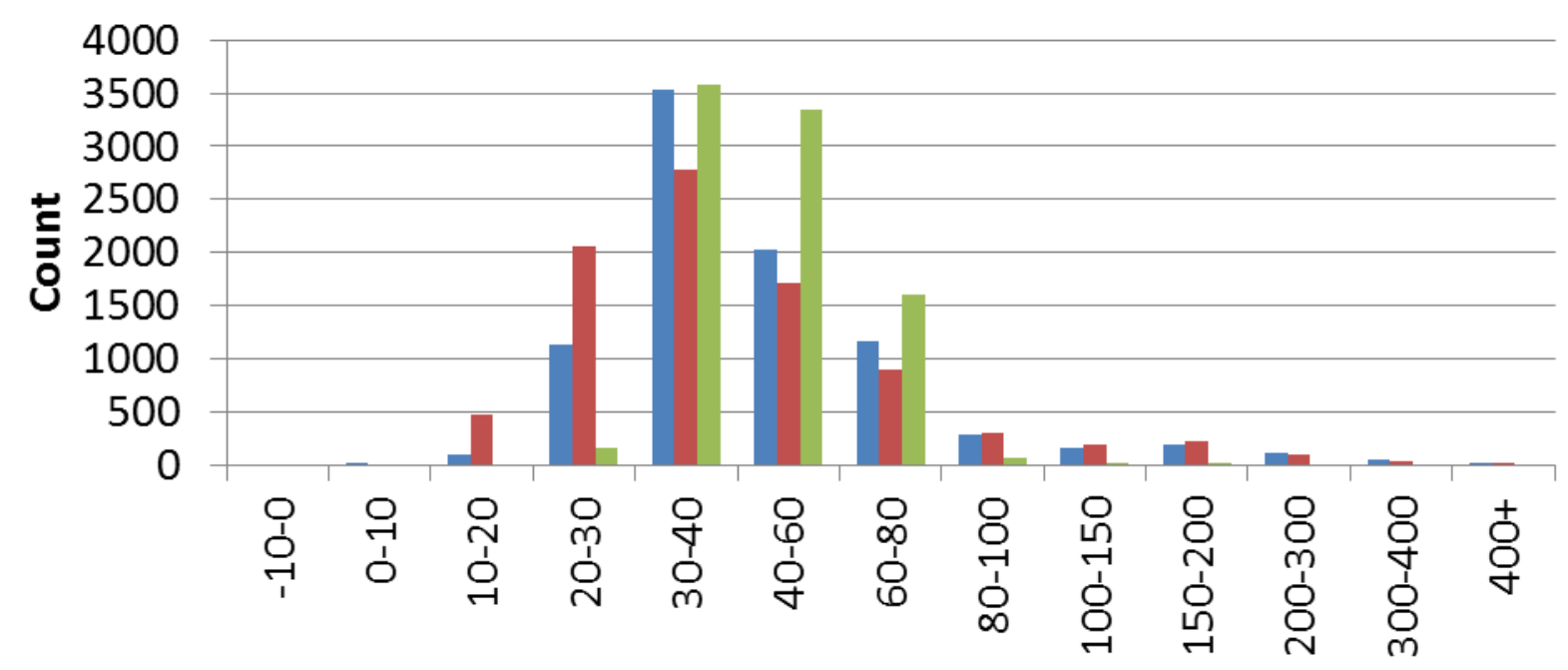

Bins

-PJM NYISO $\quad$ CAISO

Figure 11. Distribution of day-ahead energy prices for different regions in 2015

Real-time energy prices tend to be more volatile and experience larger price spikes. Figure 12 shows an example of a histogram for real-time prices from CAISO in 2015 [12]. The minimum

\footnotetext{
${ }^{4}$ Data can be found on the website for each operator (CAISO: http://oasis.caiso.com/; PJM: http://www.pjm.com/markets-and-operations/energy.aspx; and NYISO: http://www.nyiso.com/public/markets operations/market data/pricing data/index.jsp).
} 
of the selected nodes was $-\$ 3,156 / \mathrm{MWh}$ and the maximum was $\$ 3,030 / \mathrm{MWh}$. Unlike the dayahead CAISO prices, which had no instances greater than $\$ 400 / \mathrm{MWh}$, the real-time prices have on average 61 hours with prices over $\$ 400 / \mathrm{MWh}$.

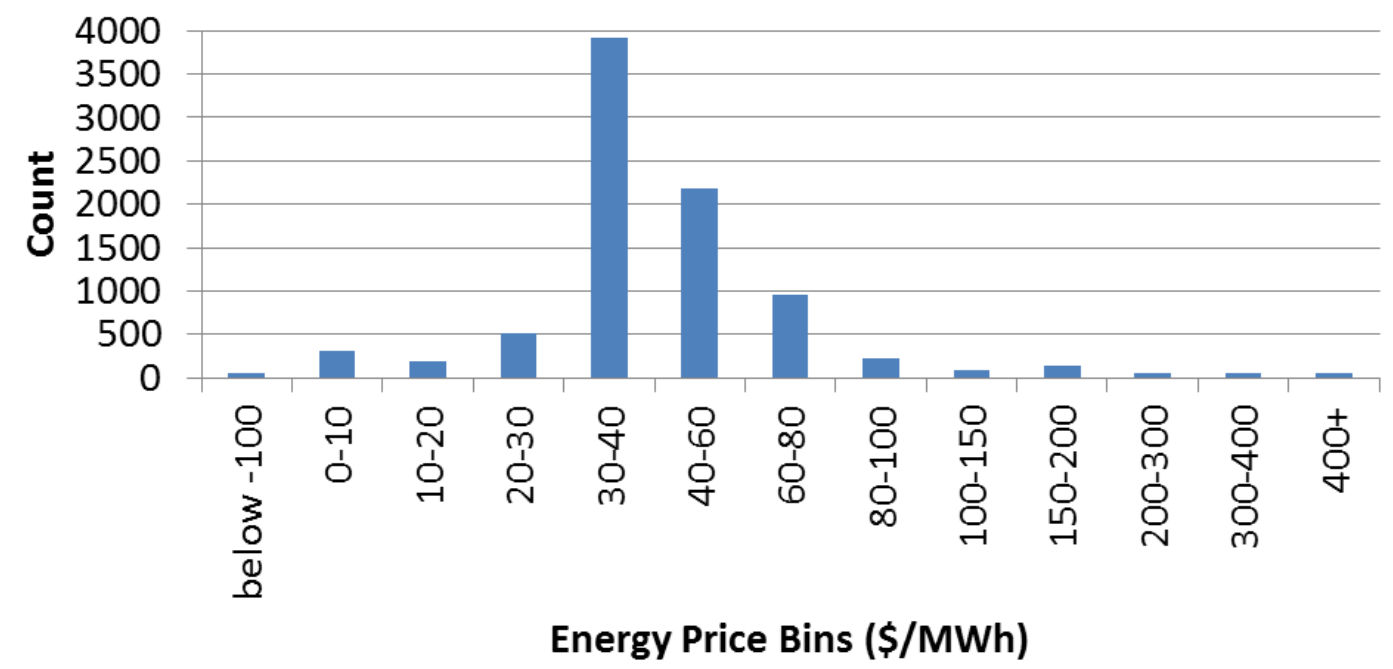

Figure 12. Distribution of real-time energy prices for several CAISO nodes in 2015.

\subsubsection{Ancillary Service Market Prices}

Ancillary service markets considered for this analysis are regulation reserve, spinning reserve, and non-spinning reserve. In addition to providing energy to support the local load, fuel cell backup units could also provide several types of ancillary services. The prices for ancillary services vary for each ISO/RTO and also for the service provided. Figure 13 depicts the average daily ancillary service price for the CAISO South region in 2015.

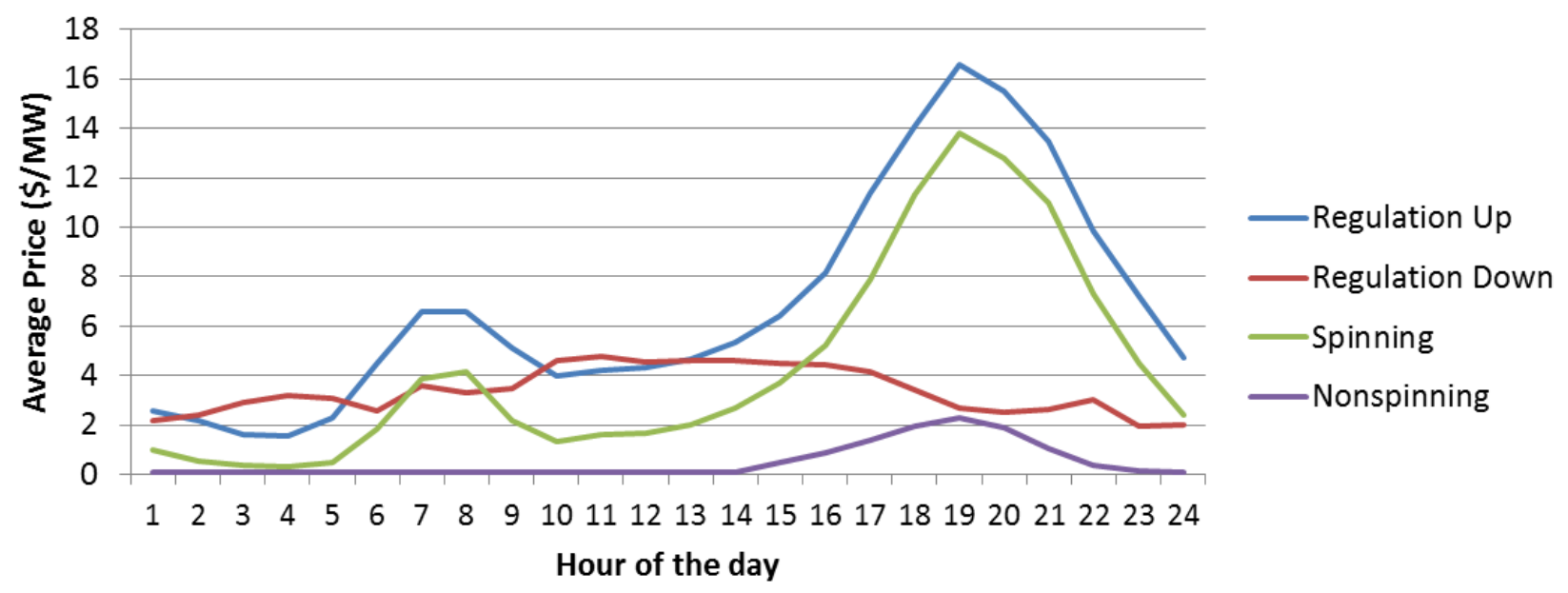

Figure 13. Average ancillary service prices for CAISO South in 2015

Regulation reserve ensures that grid frequency is maintained by providing adjustments to compensate for day-ahead and real-time energy imbalances. As shown in Figure 13, regulation is separated into regulation up (increase in generation / reduction in load demand) and regulation down (reduction in generation / increase in load demand). Spinning and non-spinning are 
contingency reserves that are called sequentially in the event of a grid outage. Spinning reserve can respond very rapidly to accommodate energy imbalances that regulation cannot handle.

Generators providing non-spinning reserve are often off at the time of the event and must turn on rapidly to provide service, if needed. Non-spinning reserve replaces spinning reserve, which can, in turn, be replaced by other reserves to prepare for another outage. The regulation reserve is the most valuable ancillary service, followed by spinning reserve, and lastly, non-spinning reserve.

\subsubsection{Potential Value for Energy Market Participation}

The cost of hydrogen delivery and storage limits the frequency that the fuel cell can provide generation and participate in additional markets. A high hydrogen price discourages participation unless the electricity price is very high, whereas a low hydrogen price encourages greater participation in providing load reduction and grid services. In the 2014 NREL study, 8-hour and 72-hour runtime scenarios of the fuel cell backup power were examined. The 8-hour scenario assumes that the hydrogen storage unit is a pack of rented hydrogen gas bottles that are swapped out when the gas is low; the 72-hour runtime scenario assumes a fuel cell system with a hydrogen storage module that is purchased and refilled in place, instead of using bottle swapping. There is a fixed cost to receive a delivery truck of hydrogen and a cost for the hydrogen molecules. From the 2014 NREL study, the base cost for 8 hours of hydrogen using delivered bottles was $\$ 100$ fixed and $\$ 10 / \mathrm{kg}$. By installing a fill-in-place system, the costs dropped to $\$ 50$ fixed and $\$ 8 / \mathrm{kg}[2]$.

For this study, we assume that having only 8 hours of storage means that all of the hydrogen must be conserved for emergency purposes. So we focused on systems with greater than 8 hours of storage that are willing to consume some hydrogen for supporting the grid. As a result, the default price considered is $\$ 50$ fixed and $\$ 8 / \mathrm{kg}$. Several sensitivities are performed to understand the impact of reducing the cost of each component. One sensitivity study explores the impact of reducing the fixed price by $50 \%$ to $\$ 25$ per delivery, another sensitivity study reduces the hydrogen cost by $50 \%$, and the final sensitivity study combines both reductions. By comparing the hydrogen cost of the fuel cell against the potential range of energy price, we can assess the required electricity price to offset fuel costs. Figure 14 presents that comparison. 


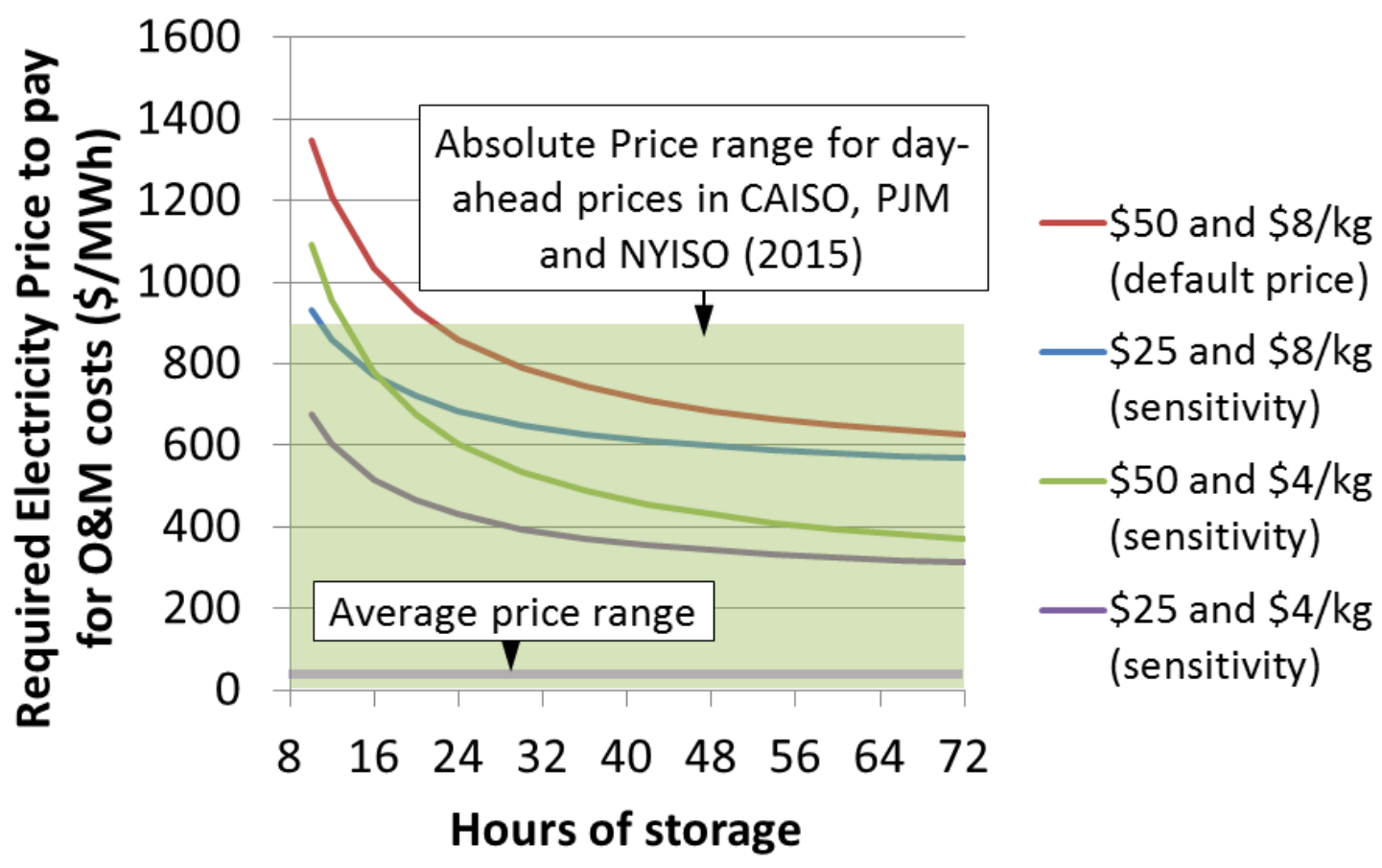

Figure 14. Electricity price by the fuel cell backup power

Figure 14 indicates that the price range for day-ahead markets is sufficient to offset the cost of fuel at the high end of the price range. From Figure 11 and Figure 12, we recognize that there are limited high-price hours where the opportunity cost of providing energy can offset the cost of hydrogen delivery. Figure 14 also shows how lowering the cost of hydrogen fueling, storage, and delivery with easy access to hydrogen supply is important for the economic return from energy markets.

\subsubsection{Potential Value for Ancillary Service Market Participation}

Using the ancillary service prices in Figure 13, we can estimate the value for ancillary service participation. Table 5 contains the anticipated value from capacity reservations for the North and South ancillary service regions of CAISO in 2015. The revenue represents the value for bidding into every hour of the year for the given service. One caveat is that we did not consider dispatch for reserves. If the fuel cell wins a contingency reserve bid (spinning or non-spinning), then the device can be called several dozen times per year, resulting in energy production and requiring additional hydrogen to refill the storage system [13]. As a result, Table 5 only represents a portion of the profit.

Table 5. Maximum Value for Reserves without Including Dispatch in CAISO in 2015

\begin{tabular}{|l|l|l|}
\hline Reserve Services (\$/kW/year) & CAISO North & CAISO South \\
\hline Non-spinning reserve & 2.6 & 4.3 \\
\hline Spinning reserve & 24.9 & 37.9 \\
\hline Regulation down & 27.0 & 29.7 \\
\hline Regulation up & 41.7 & 59.5 \\
\hline
\end{tabular}


Typically when spinning or non-spinning reserves are called, it is as a result of an emergency (e.g., generator outage). During these events, the energy price is likely to be elevated, which increases the revenue; however, hydrogen will need to be consumed during that period and resupplied. Reserve events typically last around 10 minutes, but reserves must be available to provide several hours of energy if requested by the system operator [11]. Regulation is called even more often than spinning and non-spinning reserves; and because dispatch of regulation occurs during both emergencies and normal grid operation, the energy price is not likely to be high enough to offset hydrogen fuel costs. Thus, the most viable markets for fuel cell backup units that provide revenue without requiring significant hydrogen consumption are spinning reserves and non-spinning reserves.

\subsubsection{Lifetime Impacts}

A concern that arises when considering a greater number of hours of operation per year is the impact on system lifetime. Backup power systems are typically designed to be low cost with low utilization, a good match for cell tower needs. And the fuel cell systems must perform a system health check regularly to ensure availability when emergency backup power is needed. It is possible to align the fuel cell system check with participation in electricity markets for a marginal increase in revenue and to keep operation hours below the preferred limit based on supplier input.

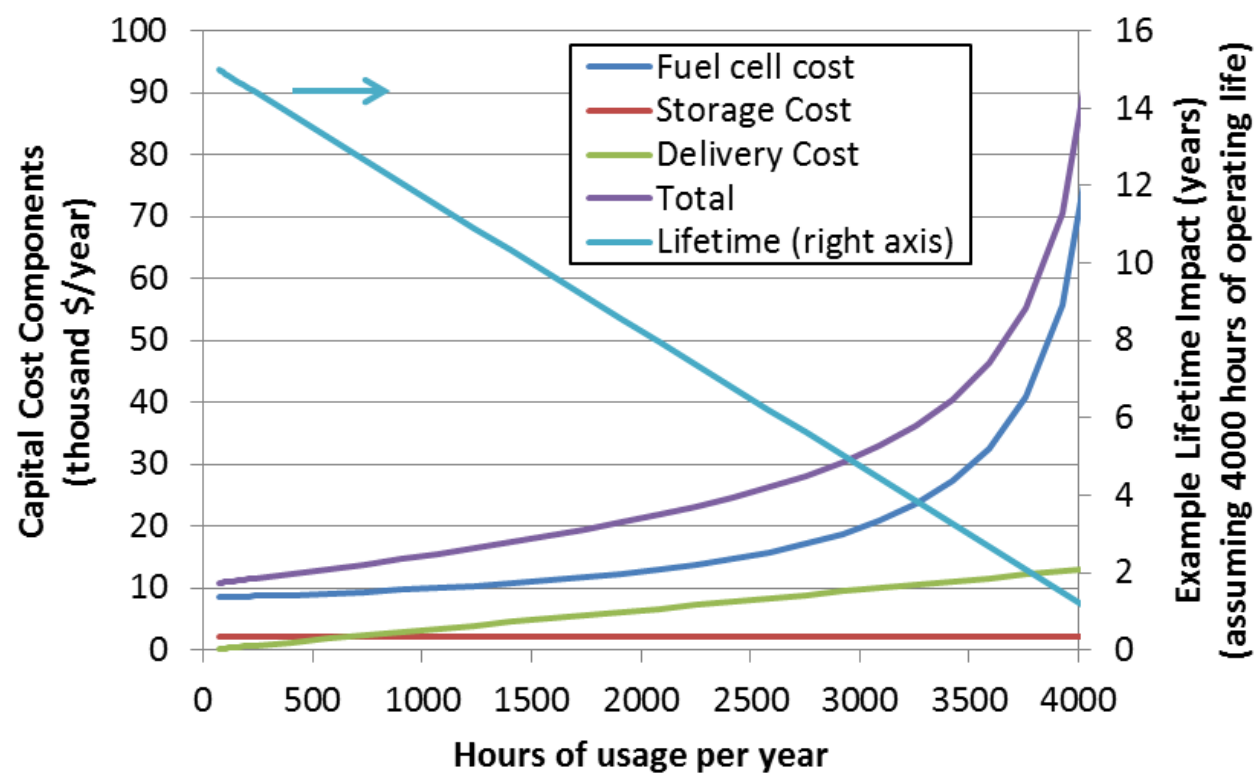

Figure 15. Relative capital cost increases for 72-hour systems from reductions in lifetime due to greater usage

To assess the economic impact of operating the fuel cell system more often, we leverage the basic technical and economic information (e.g., equipment cost, delivery cost, and efficiency) necessary to conduct a benefit/cost analysis [2]. The assumed lifetime for the fuel cell backup units is 15 years. Figure 15 shows the relative capital cost increases per year from the reduction in fuel cell lifetime due to increased running hours. The curve includes the fuel cell cost and indicates that great usage of the current fuel cell system will not compensate the fuel cell cost sufficiently to warrant high usage from a fuel or capital cost perspective. Therefore, the use of 
backup power should be limited to providing reserve capacity with limited hours of dispatch or for energy markets with high prices.

\subsubsection{Additional Requirements}

There are several requirements for participating in energy or ancillary service markets within the territory of an ISO or RTO. First, the aggregated capacity of backup devices must be greater than $100 \mathrm{~kW} .^{5}$ Additionally, customers need to verify their participation with the ISO/RTO, which, for non-aggregated systems, requires communication and involves installing a meter to monitor energy flows. This meter is an additional expense and should be considered when customers are determining their value proposition.

Achieving 100-500 kW of aggregated capacity for participation in electricity markets would require tens to hundreds of backup units, depending on the individual capacity that is available for participation at each site. Because several thousand fuel cell backup units are installed, achieving an aggregation of hundreds of units within one ISO/RTO is not a limiting factor.

\section{Summary}

This feasibility study reviewed current fuel cell backup power systems for cell tower and grid distribution, studying the potential to use the backup power for providing grid services. We also studied the technology development needs for integrating fuel cell power units into a microgrid/grid connection to form virtual power plants. The results focus on additional revenue options from grid integration that supplement the critical backup need and work together with the hydration cycle to improve system economics.

The primary purpose of backup systems is to provide power in the event of a grid outage. Integrating backup systems with electricity markets and demand response programs can provide equipment owners an early warning of potential grid outages - and, more importantly, enable a more seamless transmission to islanded mode during a grid outage. Grid outages as a result of contingencies including generator outage or transmission/distribution line failures cause fluctuations in the electricity and ancillary service prices. To be dispatched in the energy markets, the energy price must be very high, which can be coincident with stress on the system. Similarly, to be dispatched in ancillary service markets, namely spinning and non-spinning, there has likely been some contingency event. Dispatch in ancillary service markets or from high energy prices signals that there is a higher chance of a grid outage. If the fuel cell system is turned on and operating before an outage event, then it can more easily transition to an islanded configuration.

Providing grid services can bring additional benefit to installations of fuel cell systems for cell towers. The fuel cell can participate in energy markets if the energy price is sufficiently high (i.e., during price spikes). These price spikes must be large enough to cover the cost of hydrogen fuel and delivery, as well as the potential system degradation resulting from additional hours of dispatch.

\footnotetext{
${ }^{5}$ CAISO requires $500 \mathrm{~kW}$ of capacity to qualify, and then one can bid as low as $100 \mathrm{~kW}$ into the markets.
} 
Participation in ancillary services provides a more predictable value and was determined to be the preferred market for fuel cells in backup-power configurations. There are challenges with aggregation of units, and monitoring and reporting the changes that must be addressed. Celltower communication networks are ideal for monitoring and can also be used to communicate information to a central server for analysis and management. Monitoring and data-transmission subsystems may be necessary for the systems to be connected and coordinated for operation. The connected systems make it possible to adapt to the grid situation for economic returns to the owner.

Although the usage of small-scale backup power systems for grid services is not favorable immediately, the technology advances indicated above can bring expanded application and economic returns to future backup power systems. The technical recommendations from this project include:

- Networking fuel cell backup power to create a larger dispatchable resource within a region.

- Developing fuel cell backup-power grid service hardware (such as a controller) and software (as in Figure 10).

- Developing a monitoring and communication strategy to reduce the cost of participating in energy markets and ancillary services.

- Considering future market trends and investigating the potential of fuel cell backup power to provide grid service and demand response for additional economic benefits.

- Studying long-term market potential in an increasingly renewable grid and a changing world for more reliable and flexible power supply for the electric power needsincluding data centers, hospitals, and military uses - in the form of grid-tied and microgrid configurations.

- Addressing hydrogen storage cost, which is a major limiting factor for operating the fuel cell system as a grid resource. Future development and deployment of hydrogen supply chain (e.g., vehicle fueling infrastructure) can impact the delivery price for hydrogen and the cost of hydrogen equipment.

- Investigating alternative configurations that increase value added from grid services. See Appendix A for a preliminary list of alternative configurations.

With increased fuel cell backup-power installations and more renewable generation on the grid, providing grid services with the configuration and control strategy introduced above can increase the value of the fuel cell backup system and improve the installation payback time. 


\section{References}

1. J. Kurtz, G. Saur, and S. Sprik, Hydrogen Fuel Cell Performance as Telecommunications Backup Power in the United States, NREL/TP-5400-60730, March 2015, National Renewable Energy Laboratory, http://www.nrel.gov/docs/fy16osti/60730.pdf.

2. J. Kurtz, G. Saur, S. Sprik, and C. Ainscough, Backup Power Cost of Ownership Analysis and Incumbent Technology Comparison, NREL/TP-5400-60732, 2014, http://www.nrel.gov/docs/fy14osti/60732.pdf.

3. EG\&G Technical Services, Fuel Cell Handbook, 7th Edition ed. 2004, https://www.netl.doe.gov/File\%20Library/research/coal/energy\%20systems/fuel\%20cells/FC Handbook7.pdf.

4. J. Kurtz, G. Saur, S. Sprik, and C. Ainscough, "Fuel Cell Backup Power Technology Validation," presented at Intelec 2012: 34th International Telecommunication Energy Conference, October 1, 2012, Scottsdale, Arizona, National Renewable Energy Laboratory, http://www.nrel.gov/docs/fy13osti/56785.pdf.

5. "Hydrogen and Fuel Cells for Resiliency: Fuel Cells for Telecom," Clean Energy States Alliance webinar, 2016, Clean Energy Group, http://www.cesa.org/assets/2016Files/Webinar-Slides-3.17.16.pdf.

6. J. Eichman, “Hydrogen Energy Storage: Experimental Analysis and Modeling,” Fuel Cell Technologies Office webinar, August 19, 2014, National Renewable Energy Laboratory, http://energy.gov/sites/prod/files/2014/08/f18/fcto_webinarslides_h2 storage_fc technologie s_081914.pdf.

7. S. Mullendore, Energy Storage and Electricity Markets - The Value of Storage to the Power System and the Importance of Electricity Markets in Energy Storage Economics, 2015, CleanEnergy Group, http://www.cleanegroup.org.

8. P. Asmus, K. Munson, and N. Sathe, Utility-Energy Storage Collaboration: Making Sense of New DER Business Models, Nanogrids, Microgrids, and VPPs, 2016, Navigant Consulting, Inc., http://sun-connectnews.org/fileadmin/DATEIEN/Dateien/New/Sunverge_NavigantWhitePaper4-202016FINAL-1.pdf.

9. "Hydrogen and Fuel Cells for Resiliency: Microgrids for Grid Power," Clean Energy States Alliance webinar, 2016, Clean Energy Group, http://cesa.org/webinars/microgrids-for-gridpower $/$ ?date $=2016-06-16$.

10. M. Lawrence and E. Woods, The Energy Cloud Emerging Opportunities on the Decentralized Grid, white paper, 2Q 2015, Navigant Research, https://www.navigantresearch.com/research/the-energy-cloud. 
11. The GridWise Architecture Council, GridWise Transactive Energy Framework Version 1.0, PNNL-22946 Ver1.0, January 2015,

http://www.gridwiseac.org/pdfs/te framework_report_pnnl-22946.pdf.

12. Real-time prices from the following nodes: POD_RVRVEW, CLOVIS_1_N101, DUNLAP_6_N001, GATES_6_B1, JAMACHA_6_N001, LSPSTAS_ $2, \overline{\mathrm{N}} 011$, PICO_1_N001, SANLUIS4_7_N001, SPANSHCK_6_N001, VALCNTR_6_N001, ZANKER_1_N001, California ISO Open Access Same-time Information System (OASIS) website, http://oasis.caiso.com/mrioasis/logon.do.

13. B.J. Kirby, Demand Response for Power System Reliability: FAQ, ORNL/TM-2006/565, 2006, Oak Ridge National Laboratory,

http://www.consultkirby.com/files/TM 2006565 Demand Response For Power System Reliability FAQ.pdf.

14. Z. Ma, A. Pesaran, V. Gevorgian, D. Gwinner, and W. Kramer, "Energy Storage, Renewable Power Generation, and the Grid-NREL Capabilities Help to Develop and Test Energy Storage Technologies," IEEE Electrification Magazine, September 2015, 2(3), 30-40, http://ieeexplore.ieee.org/document/7229452/?arnumber=7229452. 


\section{Appendix A: Alternative Configurations for Fuel Cell System Grid Support}

We looked into the hardware module and control algorithm for intelligent management of distributed renewable generation with the grid demand. For example, a system must determine when to operate or bid its capacity to the grid (i.e., based on site electricity demand, utility rate, energy price, ancillary service prices, lifetime impact, membrane hydration). The smart control module will be tied to the grid to determine how to best interact with the grid.

To expand the possible applications of this work, we also considered other potential locations including buildings, data centers, hospitals, and military installations with grid-connected or nano/microgrid configurations. The following application scenarios may be adaptable from the outcomes of the current studies:

Scenario 1: Fuel cell power systems for distributed generation or transportation with grid integration and intelligent control.

Fuel cell distributed generation systems are highly suitable for microgrids and critical loads. Building-integrated fuel cell systems have been broadly deployed, and many of them also are grid-tied. Future fuel cell electric vehicles may also play a role in grid integration with the possibility to fill vehicles with hydrogen produced at times of lower grid demand, and to generate power for buildings or homes at peak demand hour when cars are parked. The modelgenerated control algorithm can be used for building or home smart-power production by plug-in fuel cell electric vehicles in balance with grid demand and electricity price, and as emergency backup power.

Some telecom cell towers are located on top of or near buildings that may be integrated with the building backup power systems by using quiet, zero-emission fuel cell systems. In such applications, the fuel cell may also supply critical load for the building, and integrate with local heat demands. The integration can benefit cell tower owners as well as building owners. The fuel cell suppliers may consider such an application scenario and design the product for suitable usage for microgrid or VPP configurations in a combined system of cell tower and building backup power.

Scenario 2: Fuel cell backup power system for airport and airport service vehicles powered by fuel cells and generating power in the idle peak hours, or other industrial uses. The fuel cell power system can increase airport power security and reduce points of pollution.

The airport service support vehicles currently used by airlines are purely diesel-engine based and provide aircraft ground services. Diesel engines emit a significant amount of pollutants and are points of pollution in an airport. The fuel-cell-powered service vehicles have great potential for airport support with their clean and efficient merits. Those vehicles are usually clustered within the airport; thus, the supply of hydrogen fuel is easy and costs are lower. Their higher efficiency and water as exhaust can reduce the total fuel consumption and achieve zero on-site emission. In addition, those vehicles in their idle time may tie to the power network and form a microgrid within the airport to produce power, to be peak-shaving power generation [8] to balance the grid peak demand, and to improve the airport electricity reliability and economics. Lastly, on-site 
production of hydrogen from electrolysis can be considered, which will provide an opportunity to further integrate with the electric grid by providing local energy management as well as support to the larger grid.

Scenario 3: Military base in forward-deployed locations, where the fuel transportation cost is very high. A solar-driven electrolyzer for hydrogen supply within the fuel cell microgrid could be efficient, reliable, economic, clean, and quiet power generation for the forward-deployed military base.

The Pentagon estimates that one gallon of fuel can cost as much as $\$ 13$ if shipped by ground to forward-deployed locations. The cost can rise to $\$ 400$ per gallon if it has to be transported via helicopter in dangerous areas. Reducing the amount of fuel consumed to produce electricity at forward-deployed bases allows it to be diverted to operate other critical equipment, resulting in a huge cost savings. Lightweight, high-efficiency renewable energy systems can replace costly diesel generators at these forward-deployed locations and provide power with reduced cost and carbon emissions.

Scenario 4: Emergency, backup, and disaster relief power for critical facilities such as data centers, hospitals, search and rescue, shelters, and water supply and treatment.

Life-supporting systems in a hospital depend greatly on a reliable power supply. Data centers are the brain of a modern society and they house government data, financial data, and data-formatted information. Fuel cell backup systems of different sizes and configurations can be tailored for these different application needs. Digester gas generated from water treatment facilities can also be used as fuels for high-temperature fuel cells to benefit the environment and reduce the fuel cost of such plants. 


\section{Appendix B: Key Resources for Future Studies}

NREL has suitable infrastructure to perform microgrid and grid-connected studies. NREL's Energy Systems Integration Facility (ESIF) can be used to study fuel cells operating in island mode or grid connection. ESIF was designed to conduct research and development on variousscale integrated systems. The facility contains large-scale battery and photovoltaic (PV) simulators, together with megawatt-scale grid simulation, to develop new integrated systems that include energy storage. Figure B-1 shows a diagram of an experimental system for grid and vehicle systems integration that enables hardware and hardware-in-the-loop simulation of command, communication, and control systems, while maximizing the benefits of energy provided by renewable resources.

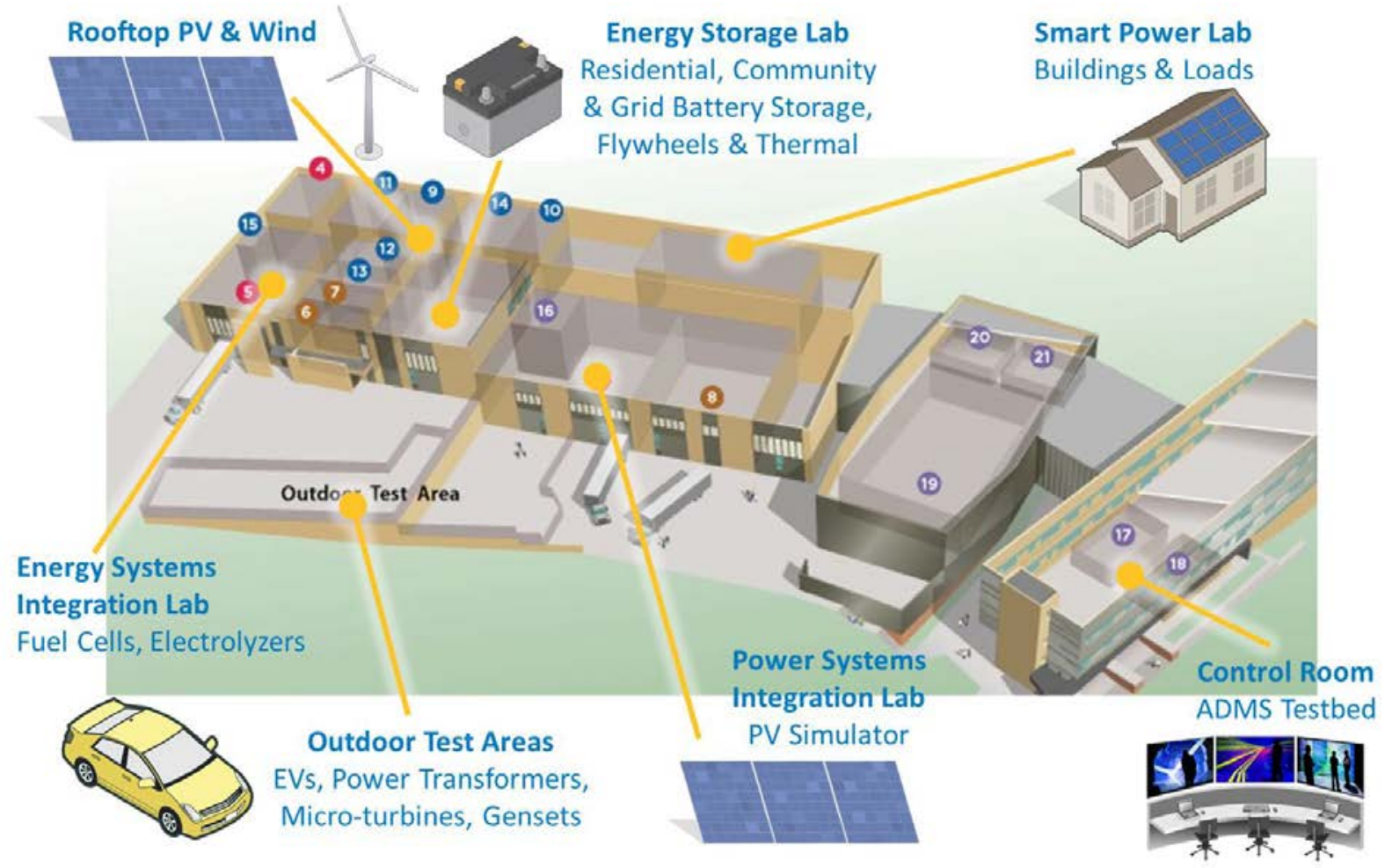

Figure B-1. DOE's ESIF can be a test base for a fuel cell backup power system integrated with renewable power and hydrogen and the ability for grid service [14]

The uniqueness of the ESIF is that energy storage can be tested in ways not possible at other existing test facilities - namely, testing of energy storage as follows:

- As a standalone system connected directly to the Xcel Energy electrical grid with the smart-grid interface monitor and controls

- In combination with renewable generation sources such as the National Wind Technology Center and ESIF wind turbines and PV arrays connected to the Xcel grid

- For energy management and storage testing in combination with renewable generation sources connected to the controllable grid interface. 
As one of the key resources of DOE's Office of Energy Efficiency and Renewable Energy, ESIF can be used to model both PV and battery technologies. PV generation is approaching grid parity in many regions of the world. ESIF can link to grid operators to gather up-to-the-minute measurement and forecast data from distributed energy sources and optimize system performance using sensor, communications, and data analytics technologies. These software and hardware solutions can be capable of real-time system operation and planning, which will allow testing of the distributed generation/grid integration for operating modes. 